DIW BERLIN

Discussion

Papers
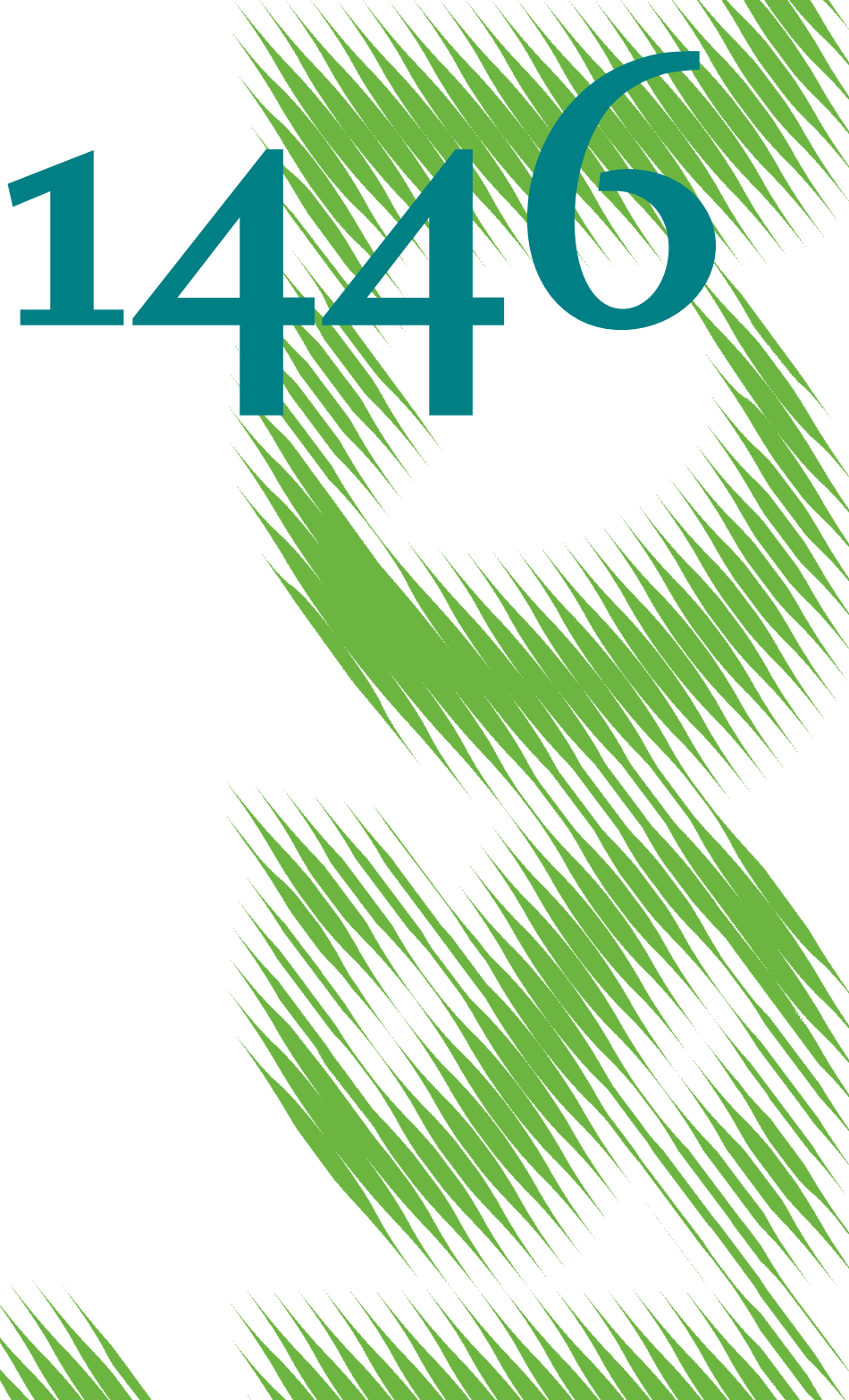

Public Health Insurance and Entry into Self-employment 
Opinions expressed in this paper are those of the author(s) and do not necessarily reflect views of the institute.

IMPRESSUM

(C) DIW Berlin, 2015

DIW Berlin

German Institute for Economic Research

Mohrenstr. 58

10117 Berlin

Tel. +49 (30) $89789-0$

Fax +49 (30) $89789-200$

http://www.diw.de

ISSN electronic edition 1619-4535

Papers can be downloaded free of charge from the DIW Berlin website:

http://www.diw.de/discussionpapers

Discussion Papers of DIW Berlin are indexed in RePEc and SSRN:

http://ideas.repec.org/s/diw/diwwpp.html

http://www.ssrn.com/link/DIW-Berlin-German-Inst-Econ-Res.html 


\title{
Public health insurance and entry into self-employment ${ }^{*}$
}

\author{
Frank M. Fossen ${ }^{\dagger} \quad$ Johannes König $^{\ddagger}$
}

January 27, 2015

\begin{abstract}
:
We estimate the impact of a differential treatment of paid employees versus self-employed workers in a public health insurance system on the entry rate into entrepreneurship. In Germany, the public health insurance system is mandatory for most paid employees, but not for the self-employed, who usually buy private health insurance. Private health insurance contributions are relatively low for the young and healthy, and until 2013 also for males, but less attractive at the other ends of these dimensions and if membership in the public health insurance system allows other family members to be covered by contribution-free family insurance. Therefore, the health insurance system can create incentives or disincentives to starting up a business depending on the family's situation and health. We estimate a discrete time hazard rate model of entrepreneurial entry based on representative household panel data for Germany, which include personal health information, and we account for nonrandom sample selection. We estimate that an increase in the health insurance cost differential between self-employed workers and paid employees by 100 euro per month decreases the annual probability of entry into self-employment by 0.38 percentage points, i.e. about a third of the average annual entry rate. The results show that the phenomenon of entrepreneurship lock, which an emerging literature describes for the system of employer provided health insurance in the USA, can also occur in a public health insurance system. Therefore, entrepreneurial activity should be taken into account when discussing potential health care reforms, not only in the USA and in Germany.
\end{abstract}

JEL classification: L26, I13, J2.

Keywords: Health insurance, entrepreneurship lock, self-employment.

\footnotetext{
* Acknowledgement: We would like to thank Robert Fairlie, Viktor Steiner, and participants at various seminars for valuable comments. Frank Fossen conducted part of this project as a visiting researcher at the University of California, Santa Cruz. He thanks the Fritz Thyssen Foundation for financial support of this research visit.

${ }^{+}$Freie Universität Berlin, School of Business \& Economics; DIW Berlin, and IZA. Corresponding author, address: Freie Universität Berlin, Boltzmannstr. 20, 14195 Berlin, Germany, phone: +49 30 83852510, fax: +49 30 838452510, e-mail: frank.fossen@fu-berlin.de.

${ }^{\ddagger}$ Freie Universität Berlin, School of Business \& Economics.
} 


Abbreviations:
HICD Health insurance cost differential
PHI Private health insurance
PIT Personal income tax
SHI Statutory health insurance

\section{Introduction}

Historically health insurance systems were derived from the desire to protect paid employed workers, with the implicit assumption that the self-employed are in a position to take care of themselves. Such health insurance systems implicitly create various incentives or disincentives to forego paid employment and start up as an entrepreneur. An emerging literature finds that employer provided health insurance in the USA implies an entrepreneurship lock effect in the sense that workers insured through their employers are reluctant to enter into self-employment because they do not want to lose their insurance coverage (e.g., Holtz-Eakin et al., 1996; Fairlie et al., 2011). However, almost nothing is known about the effects of public health insurance systems on entrepreneurial activity. Closing this gap in the literature is an important task. Health care systems are frequently overhauled in many countries, not least because of the challenges posed by ageing populations. The Patient Protection and Affordable Care Act is a well-known example of a far-reaching health care reform that introduces elements of a public health insurance system in the USA. Given the importance of entrepreneurship in modern knowledgebased economies with respect to innovation, growth, and employment creation (according to Carree and Thurik, 2003; Acs and Audretsch, 2005; Van Praag and Versloot, 2007), it is crucial to learn about effects of changes to public health insurance systems on entrepreneurial activity. ${ }^{1}$

The German health care system is particularly well suited to study such effects, because it creates significant variation in incentives and disincentives for self-employment across workers

\footnotetext{
${ }^{1}$ Blanchflower et al. (2001) report that $64 \%$ (57\%) of West (East) Germans say they would prefer to be selfemployed, but the actual self-employment rate is only $10 \%(6 \%)$. The authors document that this gap is large across all of the 23 industrial countries included in their analysis. This sizable latent supply of entrepreneurs suggests that there is potential to raise actual entrepreneurship rates by reducing barriers and setting incentives.
} 
that changed frequently over time and can be exploited for identification. In the German hybrid system, public and private health insurance co-exist in a highly regulated legal framework. Germany's health care system is sometimes referred to as the Bismarck model; variants of this model can also be found in other countries in continental Western Europe, Asia, Latin America, and in many of the formerly communist countries in Central and Eastern Europe (Gerlinger and Schmucker, 2009). ${ }^{2}$

In Germany, public health insurance is obligatory for most paid employees, while the selfemployed can generally choose between private health insurance and voluntary membership in the public health insurance system after leaving paid employment. While public health insurance contributions are a percentage of gross labor income, premiums in private health insurance depend on age and a health assessment at entry, and until 2013 also on gender. Contribution rates into public health insurance varied by statutory health insurance providers until 2008. Importantly, membership in public health insurance allows a spouse with income below a certain threshold and children to be covered by family health insurance for free, while private health insurance must be purchased for each family member. Therefore, when an individual considers switching from paid employment to self-employment, the differential in health insurance costs between the two alternatives depend on the family situation and the age, gender, and health status of all family members. Legal changes in the deductibility of health insurance contributions from the personal income tax base in 2005 and 2010 provide additional variation.

We use the Socio-economic Panel (SOEP), a representative household panel survey for Germany, which provides detailed individual information on employment transitions and the determinants of self-employment known from the literature, as well as health insurance

\footnotetext{
${ }^{2}$ Even in countries not following the Bismarck model, public and private health insurance often co-exist. For example, Besley et al. $(1998,1999)$ analyze the interactions between the public and private health care sectors in the UK.
} 
coverage and the health situation of the household members. This allows us to simulate the individual health insurance cost differential between the two alternatives of self-employment and paid employment. Carefully controlling other potentially relevant factors such as income, age, gender, and health of the family members, we estimate the effect of the cost differential on the probability of entry into self-employment for paid employees. A discrete time hazard rate model avoids survivorship bias in the sample of paid employees, and we control for non-random selection into this sample.

The results indicate that an increase in the health insurance cost differential between selfemployment and paid employment by 100 euro per month (the standard deviation is 120 euro) decreases the probability of entry into self-employment by 0.38 percentage points, i.e. about a third of the average annual entry rate. This shows that entrepreneurial activity is sensitive to changes in the health insurance system that alter the cost differential. Further investigation shows that men respond more strongly to these incentives than women. The results are robust with respect to specification choices and assumptions with regard to the health insurance cost differential. Our conclusions are also supported when we estimate reduced-form models with the determinants of the health insurance cost differential as explanatory variables instead of the cost differential itself.

In the following section, we provide an overview of the relevant literature and point out our contributions. Section 3 briefly describes Germany's hybrid system of public and private health insurance as well as the tax deduction. Section 4 is devoted to the empirical methodology, and Section 5 describes the household panel data we use. The empirical results are provided in Section 6, and Section 7 concludes the analysis.

\section{Extant literature and our contributions}

The emerging literature on entrepreneurship lock has its roots in the job-lock literature. This literature describes the barrier that employer provided health insurance potentially poses on job 
mobility in the USA, since employees may fear to lose coverage for pre-existing conditions if they switch their employer (e.g., Madrian, 1994; Gilleskie and Lutz, 2002). In their eclectic theory of entrepreneurship, Verheul et al. (2002) note that health insurance systems increase the costs of entrepreneurship if the transition to self-employment implies that the current health insurance coverage must be given up. Holtz-Eakin et al. (1996) pioneer the empirical analysis of entrepreneurship lock in the USA using the Survey of Program Participation and the Panel Study of Income Dynamics. They investigate if the negative influence of employer-provided health insurance on the probability of transition from paid employment to self-employment decreases if the switching person can be covered by the spouse's health policy; they also explore the impact of family size. The authors cannot draw clear conclusions because of large standard errors. These may result from the inefficiency of the method, which uses only very limited variation. In our analysis, we exploit significantly more variation on a continuous scale of cost differences.

Using a similar strategy as Holtz-Eakin et al. (1996), but the larger, Current Population Survey (CPS), Wellington (2001) finds a significant positive effect of having health insurance through one's partner on the probability of being self-employed. Also based on the crosssectional CPS, Lombard (2001) similarly reports that married women are more likely to be selfemployed if their husbands have health insurance. Estimating probability models of being selfemployed implies potential issues of survival bias and reverse causality. We improve on this by estimating hazard rate models of the probability of entry into self-employment based on panel data, where the explanatory variables are observed before a transition is made.

Zissimopoulos and Karoly (2007) focus on self-employment at older ages using the Health and Retirement Study, include indicators of own and spousal health insurance coverage in their empirical transition model, and conclude that their results are only partly reconcilable with job lock. They note that employers who provide health insurance in the USA may also tend to offer quality jobs, which may confound the analysis, as also emphasized by Gilleskie and Lutz 
(2002). In our German setting, all paid employees with labor income below a fixed threshold are obliged to be covered under statutory public health insurance, so the issue of correlations of unobserved job heterogeneity and health insurance coverage do not occur.

Fairlie et al. (2011) link consecutive CPS surveys to create a short two-year panel, which allows them to study business creation using the large data base. Their approach exploits a discontinuity at age 65 , which is the threshold when coverage under Medicare begins in the USA. This should make the loss of employer-provided health insurance less relevant and therefore facilitate entry into self-employment. The results support the view that employerprovided health insurance in the USA creates an entrepreneurship lock effect.

None of the articles mentioned so far calculate health insurance costs in the alternatives of paid employment or self-employment. Therefore, the quantitative results of each paper can only be interpreted in the immediate institutional contexts of each analysis. Since we estimate a marginal effect of the individual health insurance cost differential on the probability of entry into self-employment, our estimated effect size can be interpreted more generally.

Four articles analyze the effect of the 1986 Tax Reform Act (TRA86) and its amendments in the USA on self-employment and transition probabilities. This policy reform allowed entrepreneurs to deduct increasing portions of their health insurance premiums from their taxable income. Heim and Lurie (2010) and Gurley-Calvez (2011) use a panel of tax return data, whereas Velamuri (2012) and Gumus and Regan (2014) employ CPS data. The results from the four articles suggest that a lower after-tax price of health insurance in self-employment increases the self-employment and entry rates and decreases the exit rate, although Gumus and Regan (2014) do not find a significant effect on the entry probability.

The extant literature is limited to considering the health insurance system in the USA, which is dominated by employer-provided health insurance. The literature lacks microeconometric investigations of the effects of public health insurance systems on the probability of entry into self-employment. Most countries in the world implement some type 
and some extent of public health insurance, and this is also relevant for the USA since the introduction of the Patient Protection and Affordable Care Act. Jackson (2010) provides the only study considering state mandated health insurance, also in the USA. He estimates that Massachusetts' health insurance mandate policy implemented in 2007 decreased the likelihood of new firm formation in Massachusetts versus neighboring New Hampshire in the border region. He attributes this to the higher financial burdens for entrepreneurs brought by the policy. Again, in contrast to our study, this cost increase is not quantified, which makes it difficult to relate the effect size to other contexts.

A related, but distinct stream of literature investigates the determinants of health-insurance coverage of the self-employed. This issue is of special interest in the USA, where a large number of self-employed persons lack health insurance (Perry and Rosen, 2004). A number of articles (Gruber and Poterba, 1994; Heim and Lurie, 2009; Selden, 2009; Gumus and Regan, 2013) estimate the impact of the improved tax deductions of health insurance premiums brought by TRA86 on health insurance demand among the self-employed. They all find significant effects in the expected direction, which provides another indication that the self-employed respond to monetary incentives in the context of health insurance.

\section{Germany's hybrid health insurance system}

\subsection{Statutory and private health insurance}

Germany's health care system is characterized by the co-existence of public, non-profit statutory health insurance (SHI) and for-profit private health insurance (PHI). Almost 90 percent of the population is covered under SHI (Federal Ministry of Health, 2013), which is regulated by federal law, primarily the Code of Social Law V (Sozialgesetzbuch V). We cover the most important institutions and facts for Germany relevant during the period of analysis (2000-2011). 
Health care is universal in the sense that since 2009, health insurance (public or private) is obligatory for all inhabitants of Germany, and even before, only a very small fraction of the population was not covered by any health insurance. According to numbers reported by Gress et al. (2005), only 0.12 percent of the paid employees and 0.85 percent of the self-employed were not covered by any health insurance in 2003 .

Paid employees are compulsorily insured under SHI if their gross pay does not exceed the obligatory insurance limit (Versicherungspflichtgrenze). This limit is adjusted annually and increased from $€ 3297.83$ per month in 2000 (US\$3321 on 1/1/00) to $€ 4125.00$ in 2011 (\$5502 on 1/1/11). Employees with higher salary can opt out of the SHI system and choose PHI instead, which is offered by for-profit private insurance companies.

The SHI system is based on the idea of solidarity and the ability-to-pay principle. Therefore, SHI contributions are not risk-related. Instead, they are a certain percentage of the insured person's gross salary, but the latter is only considered up to the contribution assessment ceiling (Beitragsbemessungsgrenze). This ceiling is adjusted annually and was increased from $€ 3297.83$ per month in 2000 to $€ 3712.50$ in $2011 .^{3}$ Within the SHI system, insured persons can choose one of several non-profit SHI funds, also known as sickness funds. Until 2008, contribution rates differed between the SHI funds. Since 2009, there is a unique contribution rate, but SHI funds can charge an income-independent extra premium from all members if the contributions are insufficient. ${ }^{4}$ These provisions are intended to allow for some degree of competition between the SHI funds, but in practice competition is rather limited because services are regulated to a large extend and therefore very similar. The differences in contribution rates were rather small, and the extra premium was no more than $€ 8$ per month. Table A 1 in Appendix A shows the contribution rates of SHI funds and groups of SHI funds

\footnotetext{
${ }^{3}$ Until 2002, the obligatory insurance limit and the contribution assessment ceiling were identical.

${ }^{4}$ Since 2015 , extra premiums are a percentage of income.
} 
by year. Historically, most SHI funds originate from occupational groups or regions, and many insurees simply stay with their parents' SHI fund. ${ }^{5}$

Those who are covered under statutory health insurance are additionally obliged to be covered under statutory long-term care insurance. The contribution rate, payable on top of the rate for statutory health insurance, was $1,7 \%$ before and 1,95\% since 2009. Employees without children pay an additional $0.25 \%$ since 2005 . In the following, when we refer to health insurance, we mean health and long term-care insurance, if not otherwise clear from context.

The spouse of a married, paying SHI member is covered under so-called family insurance in the SHI for free as long as his or her income is below the threshold of marginal employment. This threshold was $€ 325$ until 2002 and $€ 400$ since 2003. Children of a SHI member are covered under contribution-free family insurance if they are i.) below 19 years of age, or ii.) below 24 years of age and with labor income not exceeding the marginal employment threshold, or iii.) below 26 years of age and in education.

Specific regulations apply for marginal employment. Employees earning less than the threshold of marginal employment mentioned above are covered by SHI, but do not need to pay contributions. The employer paid a contribution rate of $10 \%$ until 2002, $11 \%$ until 2007, and $13 \%$ since 2007 ; this is only relevant for our analysis in a specification where we consider that employers are able to shift the burden onto their employees. Since 2003, employee's contributions are gradually faded in within the zone of monthly income between $€ 400$ and $€ 800$ according to a formula, which includes a factor annually determined by the Ministry of Health. The employer's contribution is calculated the same way as for regular higher income.

In contrast to the SHI, premiums for PHI policies are based on risk and independent of income. PHI premiums are determined by age and an initial health assessment. In the period of our analysis, women had to pay higher premiums than men; health insurance policies sold since

\footnotetext{
5 The introduction of the more salient extra premiums may have triggered more awareness and more switching between SHI funds since 2009 (Schmitz and Ziebarth, 2011).
} 
December 21, 2013 may no longer discriminate by gender. In contrast to family insurance in the SHI system, PHI policies have to be bought for each family member, with premiums determined by each person's individual risk assessment. PHI also includes private long-term care insurance.

Contributions to SHI and long term care insurance are split between employers and employees. Until July 2005, each side paid $50 \%$ of the contributions; since then, employees pay 0.9 percentage points of the SHI contribution rate alone. In Saxony, employees pay one percentage point of the long-term care insurance contributions alone, to compensate for an additional holiday. Correspondingly, for high-income employees with PHI, the employer pays half the PHI premium insofar as this amount does not exceed the employer's maximum contribution to SHI, which is determined by the contribution assessment ceiling and the employer's SHI contribution rate. The statutory incidence of the contributions is not necessarily equal to the economic incidence. It is possible that employers are able to shift more or less of their statutory burden to the employees by paying lower wages (or vice versa). The statutory split is very salient. Employees see their contribution to SHI as a payroll deduction on their pay check, or they directly pay their share of the PHI premium, but they do not see their employer's contributions. Chetty et al. (2009) document the behavioral importance of salience of taxes. Therefore, in the main analysis we assume that the statutory pay burden equals the perceived economic burden relevant for individual decisions, i.e., the burden is roughly split by half between employers and employees. In a robustness check, we explore the assumption of a full shift of the burden onto the employees.

Self-employed persons are not obliged to be insured in the SHI system. ${ }^{6}$ They can buy PHI, or they can choose to be voluntary members in the SHI system if they were SHI members for at least 12 months immediately prior to becoming self-employed, or if they were SHI members

\footnotetext{
${ }^{6}$ Exceptions apply for artists, writers, and journalists.
} 
for at least 24 months within the last five years. Thus, those who switch from paid employment to self-employment are usually eligible for voluntary SHI membership, except for high income employees with PHI. The self-employed pay the full SHI contributions or PHI premiums, i.e. both the employer's and the employee's shares. If they are covered under voluntary SHI, they have to prove their income to their SHI fund by submitting their income tax assessment notice, otherwise the contribution assessment ceiling (see above) is used to calculate the SHI contributions. As an additional measure to prevent income-underreporting, there is a lower limit of income applicable to compute the SHI contributions of the self-employed. In general this lower limit is three quarters of a defined reference value, which is adjusted annually. It rose from $€ 2290.59$ per month in 2000 to $€ 2625$ in 2011.

\subsection{Tax deduction rules for health insurance costs}

Health insurance expenses - SHI contributions as well as PHI premiums - can be deducted from the personal income tax (PIT) base. The German PIT is directly progressive and was changed significantly within our period of observation. Marginal tax rates ranged from $22.9 \%$ to $51 \%$ in 2000 and were reduced in several steps to a range from $15 \%$ to $42 \%$ in 2005 ; in 2007 , a new tax bracket with a top marginal tax rate of $45 \%$ was introduced. ${ }^{7}$ The basic tax allowance was also increased in various steps from $€ 6,902$ per year in 2000 to $€ 8,004$ in 2011 for a single taxpayer, and double these amounts for married joint filers. The tax schedule and its changes influence health insurance costs because the deduction is worth more in terms of absolute tax savings when marginal tax rates are higher.

The rules for the tax deduction of health insurance expenses as provisional expenditures (Vorsorgeaufwendungen), in conjunction with expenses for pension and unemployment insurance, were changed in 2005 and again in 2010. In the procedure applied before 2005, all provisional expenditures are summed together, and there are three relevant ceilings for

\footnotetext{
${ }^{7}$ In addition, a mandatory so-called solidarity surcharge of $5.5 \%$ of the PIT applies.
} 
calculating the annual deduction amount. First, $€ 3,068$ minus $16 \%$ of the employee's wage income can be deducted beforehand. ${ }^{8}$ This works in favor of the self-employed, who do not have wage income; the idea is to compensate them for the absence of an employer's social insurance contributions. Remaining provisional expenditures can be deducted in full up to the second ceiling of $€ 1,334$. Finally, half of any remainder can be deducted up to the third ceiling of $€ 667$. In total, a single self-employed person could deduct up to $€ 5069$ per year, given large provisional expenditures. After the introduction of new rules in 2005, the tax authorities still perform a higher-yield test to the benefit of each taxpayer between the old and the new rules.

Starting in 2005, provisional expenditures for pension insurance were treated separately in the tax code. All other provisional expenditures, including health insurance expenses, were now deductible up to $€ 1,500$ for paid employees and up to $€ 2,400$ for the self-employed, again recognizing the lack of employer's contributions for the latter group. Following a ruling of the Federal Constitutional Court, in 2010, these ceilings were raised by $€ 400$ each. If the health insurance expenses exceed these limits, they can be deducted in full without a limit since 2010, but in this case, no other expenses within the category of other provisional expenditures are deductible anymore, and expenditures for private health insurance contributions are only deductible insofar as they cover benefits comparable to SHI.

\section{Empirical methodology}

\subsection{Hazard rate model of entry into self-employment with sample selection}

We are interested in transitions from paid employment to self-employment. In a random utility model, a person $i$ in paid employment in period $t$ chooses to switch to self-employment in the following period if utility in self-employment (se) exceeds utility in paid employment (pe). Utility $U_{i t j}$ in alternative $j \in\{s e, p e\}$ is assumed to be a function of the health insurance costs

\footnotetext{
${ }^{8}$ The ceilings mentioned in this section double for married joint filers.
} 
for the household in this alternative, $H I C_{i t j}$, observed characteristics $x_{i t}$, and an error term $\varepsilon_{i t j}$ that includes any relevant unobservables:

$$
U_{i t j}\left(H I C_{i t j}, x_{i t}\right)=\alpha H I C_{i t j}+\beta_{j}^{\prime} x_{i t}+\varepsilon_{i t j} .
$$

The parameter $\alpha$ of the health insurance costs is expected to be negative and assumed to be the same in paid employment and self-employment, because one euro disposable for consumption should yield the same utility in both employment states. The parameters $\beta_{j}$ of the characteristics $x_{i t}$ may vary across alternatives, because these characteristics may shift tastes for one or the other alternative; for example, a self-employed father may induce the offspring's wish to be self-employed as well.

The probability of entry into self-employment conditional on the $H I C_{i t j}$ and $x_{i t}$ equals the probability that utility from self-employment $U_{i t, s e}$ is higher than utility from paid employment $U_{i t, p e}$. Let entry $y_{i t}$ denote a binary variable that equals one if a person switches from paid employment to self-employment between observation times $t$ and $t+1$, and zero otherwise. Assuming that the error terms $\varepsilon_{i t j}$ follow standard normal distributions ${ }^{9}$, we obtain:

$$
\begin{aligned}
& \operatorname{Prob}\left(\text { entry }_{i t}=1 \mid H I C_{i t, s e}, H I C_{i t, p e}, x_{i t}\right)= \\
& \operatorname{Prob}\left(U_{i t, s e}\left(H I C_{i t, s e}, x_{i t}\right)>U_{i t, p e}\left(H I C_{i t, p e}, x_{i t}\right)\right)= \\
& \phi\left(\alpha\left(H I C_{i t, s e}-H I C_{i t, p e}\right)+\left(\beta_{s e}-\beta_{p e}\right)^{\prime} x_{i t}\right)=\phi\left(\alpha H I C D_{i t}+\beta^{\prime} x_{i t}\right),
\end{aligned}
$$

where the health insurance cost differential $H I C D_{i t}=H I C_{i t, s e}-H I C_{i t, p e}$, and $\beta=\beta_{s e}-\beta_{p e}$. All the explanatory variables in $x_{i t}$ as well as the $H I C D_{i t}$ are measured before potential entries into selfemployment occur, which alleviates potential endogeneity concerns. The calculation of the $H I C D_{i t}$ involves an estimation of the counter-factual health insurance costs after a transition to

\footnotetext{
${ }^{9}$ Our assumption of normally distributed errors can be motivated by the central limit theorem and leads to a probit model (e.g., Cameron and Trivedi, 2005, p. 477), whereas McFadden's (1974) assumption of i.i.d. type I extreme value disturbed $\varepsilon_{i t j}$ leads to a logit model. The probit specification has the advantage that it can accommodate the selection correction described below. Empirically, probit and logit models generally lead to similar results because of the similarity of the cumulative logistic and normal distributions.
} 
self-employment; we describe this in Section 4.2. Before estimating this probit model by maximum likelihood, two econometric issues warrant special attention in this context.

First, the probability of switching to self-employment may change with tenure in paid employment. It may decrease due to habituation, or it may increase because the experience and networks one builds up as a paid employee may help to venture out on one's own. Therefore, we include twelve dummy variables indicating the duration of the current spell in paid employment in the vector $x_{i t}$. By conditioning on this very flexible specification of the baseline hazard, the probit model of the transition probability in equation (2), estimated on the data in person-period format, can equivalently be written as a general survival model, as described in Jenkins (1995), Sueyoshi (1995), and Caliendo et al. (2010). We use annual data because the survey interviews occur once a year and the covariates are not available at higher frequencies. By applying the discrete time hazard rate model, we take into account state dependence and avoid survivorship bias. The model consistently accounts for both, right-censored spells, i.e. spells of paid employment where we do not observe the end of the spell because persons are still employed in the last year of observation, and left-censored spells, because retrospective employment history information in our data allow us to recover the correct spell duration even in case employment already started before the first survey interview of a person.

The second potential issue is that in our context, the sample at risk of the transition from paid employment into self-employment is the sample of observations currently working in paid employment. This is a non-random sub-sample, because many persons choose not to work for a wage, especially married women; some persons are unemployed; and some persons decided to be self-employed in the past already. Therefore, we estimate a model with selection correction similar to Heckman (1979). More specifically, we employ the sample selection model for binary dependent variables suggested by Van de Ven and Van Praag (1981), with entry into self-employment as a the binary outcome. The model includes a probit equation that describes the probability of selection into paid employment. It is estimated on the full sample 
including those not working and the self-employed. The error terms of this selection equation and of the hazard rate equation (2) are modelled to follow the bivariate normal distribution with correlation. The two equations are estimated jointly using the Full Information Maximum Likelihood method. ${ }^{10}$

\subsection{Health insurance cost differential for the household and control variables}

The explanatory variable of central interest in this analysis is the differential in expected costs for health insurance between the potential, currently counter-factual alternative of selfemployment and the current situation in paid employment. The relevant cost differential takes into account the deductibility of health insurance costs from the personal income tax base.

We define the health insurance cost differential (HICD) as the minimum total increase in SHI contributions and/or PHI premiums (including long-term care insurance) after taxes for the total household per month if the paid employee under consideration switches to selfemployment. It may be positive or negative, depending on the individual and household situation. ${ }^{11}$

The health insurance costs in the current situation are calculated from the information about the health insurance situation of the household members contained in our data, including the membership in one of the SHI funds listed in Table A 1 with the corresponding contribution rates. For the counter-factual situation of self-employment of one of the household members, we simulate the total household health insurance costs for the person's two options, voluntary SHI membership or PHI. To predict PHI premiums, we first run a regression of observed private

\footnotetext{
${ }^{10}$ In the transition equation (2), among other variables, we control for the number of children under the age of 17 in the household, gender, and the interaction of these variables. In the selection equation, we additionally include the number of children below three and below six years of age and their interaction terms with the gender dummy, because the presence of young children in the household is likely to influence labor force participation, especially for women, but not the choice between paid employment and self-employment after controlling for the general family situation.

${ }^{11}$ The HICD amount depends on the assumption about cost shifting from employers to employees. As mentioned before, in the baseline estimations, we assume that the perceived economic incidence equals the statutory incidence, i.e., the burden is roughly split by half. We assess the sensitivity of the results with respect to this assumption in a robustness check.
} 
health insurance premiums of actually self-employed persons on characteristics determining PHI premiums. These include the age, gender, and health when signing the PHI contract, copayments, and eligibility for government aid for civil servants and their families. Appendix B describes this estimation in detail.

The income tax deduction is simulated using an adaption of the tax-benefit microsimulation model "STSM" for Germany (Steiner et al., 2012). The simulation accounts for the details of the progressive PIT, such as joint taxation of married couples and tax benefits for families with children, and incorporates the changes in the tax code over time, such as the two reforms of the tax deduction of health insurance expenses and the changes in the tax schedule mentioned above.

To calculate the HICD, we assume that the person entering self-employment chooses the alternative of voluntary SHI or PHI that is cheaper for the household; we discuss possible implications of differences in services and benefits between the two insurance options further below. High-income paid employees who are already insured under PHI cannot choose to switch back to voluntary SHI, so for them we calculate the HICD acknowledging that they have to stay in PHI.

Concerning income, for the calculation of the HICD, we assume that the person considering to switch to self-employment expects to earn the same amount in self-employment as he or she currently earns in paid employment. This allows us to focus on the effect of the health insurance system without mixing it with the effect of income expectations that may differ between paid employment and self-employment for other reasons. The rich set of independent variables we include and flexible functions of current income control for such expectations. ${ }^{12}$

\footnotetext{
${ }^{12}$ As an example for the calculation of the HICD, consider a family forming a household with a male main earner in full-time paid employment and covered under SHI, a wife not participating in the labor market, who stays at home to take care of two young children, and a young adult daughter in paid employment with SHI. The wife and the two children are covered contribution-free under family insurance. The male bread-winner model with a nonparticipating wife reflects a traditional family model (still) wide-spread in Germany. If the main earner switches to self-employment, he can stay in voluntary SHI, but has to pay both the employee's and employer's shares of the
} 
PHI policies usually offer more benefits than SHI funds, and physicians tend to treat PHI patients preferentially, because they are often able to charge higher prices to PHI providers. Per se, this may put into question that consumers compare the two options on a cost basis only. We adopt three strategies to account for this.

First, we control for the possession of supplementary PHI policies that any SHI members can buy to supplement their benefits. Most prominently, these additional benefits typically include eligibility for a hospital room with no more than two beds and treatment by the head physician in a hospital, which full PHI policies usually also offer. This control variable should capture the individual preference for premium health insurance benefits. Second, in a robustness check, we recalculate the HICD by adding the average cost of additional private health insurance policies to the contributions of all SHI members in order to compare costs between SHI and PHI plans with more similar benefits. Third, in a radical robustness check, we assume that when considering entry into self-employment, everybody only considers PHI because of the better benefits and nobody chooses voluntary SHI, and recalculate the HICD accordingly.

The current wage and salary income as an employee may have an effect on the probability of transition to self-employment and is also correlated with the HICD because SHI contributions dependent on income. Therefore, it is important to control for income effects through a flexible functional form. ${ }^{13}$ Similarly, health, age, gender, and the number of children are important

contributions. If he switches to PHI, his wife and the young children lose their family insurance, and the family must buy PHI plans for them as well. The adult daughter remains covered under her SHI. We assume that the cheaper alternative of voluntary SHI or PHI is chosen, which minimizes the total HICD between self-employment and paid employment for the whole family. If somebody in the family is unhealthy (except the adult daughter, who is covered by SHI in any case) or the parents are older, voluntary SHI is likely to be the cheaper option for the family. In contrast, if the adult daughter switches to self-employment, nothing changes for the father, who keeps his SHI coverage, and the mother and young children, who continue to be covered under family insurance through the father's SHI membership. The adult daughter can choose voluntary SHI or PHI for herself without further consequences to the others. PHI will be cheaper for the young women if she is healthy and has higher income. Whatever the cheaper choice, the total HICD for the household differs between the different adult household members potentially entering self-employment. As another example, in a household where two unmarried adults live together and no children are present, the self-employment and health insurance choice of one person does not affect health insurance coverage of the other and only depends on the individual situation.

${ }^{13}$ We consider higher order polynomials and spline functions. 
control variables because they may have direct effects on the entry probability and are correlated with the HICD through estimated PHI premiums for the family. ${ }^{14}$ With similar reasoning, we also include the marital status and the age, health, and income of a spouse, if present. As additional control variables, we include determinants of entrepreneurship known from the literature (e.g., Parker, 2009): Education, prior working experience and prior unemployment experience, non-German nationality as an indicator of a migration background, intergenerational background (a dummy variable indicating whether the father was selfemployed when the respondent was 15 years old), and risk aversion (the self-reported willingness to take risks on a scale from 0 to 10$).{ }^{15} \mathrm{We}$ also include industry and regional dummies, as well as a full set of year dummies to control for the business cycle.

\subsection{Identification of the effect of the health insurance cost differential}

In our econometric estimation, we identify the causal effect of the HICD on the probability of entry into self-employment by exploiting variation over individuals that is exogenous after controlling for possibly nonlinear effects of income, own and spousal health, gender, marital status, the number of children in the household, and the other control variables mentioned above. After partialling out the effects of these variables, the remaining partial variation in the HICD stems from i.) the discontinuities created by the various discrete thresholds relevant for the health insurance system as well as their changes over time as described in Section 3.1, along with the variation in contribution rates over SHI funds and time; ii.) the discontinuities in the personal income tax system that affect the amount saved through the tax deduction of the health costs, and the changes in these tax rules over time, as described in Section 3.2; and iii) the effects of specifics in each family's situation, e.g., the health of the spouse and the coverage of children under free family insurance, on counter-factual health insurance costs in self-

\footnotetext{
${ }^{14}$ The effect of children on the entry probability is allowed to vary by gender by including an interaction term.

15 The general willingness to take risks is observed in 2004, 2006, and in all years since 2008. In the other years, we impute values observed for the same person in other years.
} 
employment through the impact of these specifics on PHI premiums. Therefore, for the identification of the causal effect of the HICD we use the variation created by the details of the health insurance legislation and tax code and the changes of these institutions over time, which are exogenous to the individual, as well as the health insurance cost consequences of own and spousal health shocks, which can reasonably be assumed to be exogenous as well after controlling for income and education.

\section{Representative household panel data with health information}

\subsection{Individual household panel data}

The data requirements for this analysis are fulfilled by the German Socio-Economic Panel (SOEP), a representative annual household survey collecting detailed information about the socio-economic situation of private households in Germany (cf. Wagner et al., 2007). We use the waves 2000, when the SOEP was significantly enlarged, through $2012 .{ }^{16}$ During this time, the SOEP covered about 20,000 persons in 11,000 households. The data allow us to observe employment transitions and provide all details necessary to simulate the HICD, including the PIT deduction, as well as a rich set of control variables.

In particular, we require health information of the household members for an adequate prediction of counter-factual PHI premiums in case of self-employment, and as control variables in the transition equation. In our main specifications, we use a self-assessed health measure provided annually in the SOEP. Respondents are asked how they would describe their current state of health on a five-point scale (1=very good; $2=$ good; $3=$ =satisfactory; $4=$ poor; $5=$ very poor). Such subjective measures are commonly used in the literature (e.g., Benitez-Silva and Ni, 2008; Haan and Myck, 2009) and are generally viewed as good overall reflections of individual physical as well as mental health, at least if the analysis is confined to a single

\footnotetext{
${ }^{16}$ The last year is only used to determine if a transition to self-employment occurred between 2011 and 2012.
} 
country. Kalwij and Vermeulen (2008) report that objective health measures add little on top of self-reported health information in an analysis of employment patterns in Germany. Nevertheless, in a robustness check, we alternatively use a more objective measure, the official degree of disability, a percentage asserted by a public medical officer and printed in an official document that grants access to certain benefits. The advantage of the subjective measure is that smaller and temporary differences in a generally good medical condition are captured, which would not lead to the issuance of a disability certificate.

Since we focus on transitions from paid employment to self-employment, note that selfemployment and entrepreneurship do not necessarily denote the same concept: Entrepreneurship usually implies risk bearing and innovation, whereas self-employment goes along with income risk but not necessarily with innovation. The classification of individuals as self-employed is based on a survey question about the occupational status of each respondent. If respondents are employed or self-employed in more than one position, they are asked to report their status in their primary activity. The sample is restricted to working-age individuals between 19 and 59 years of age to avoid distortions through early retirement decisions. It excludes farmers, civil servants, pensioners, and those currently in education, vocational training, or military service; occupational choices in these groups are likely to follow different patterns. It also excludes family members working for a self-employed relative because these individuals are not entrepreneurs in the sense of running their own business.

\subsection{Descriptive statistics by employment state}

Table 1 shows the means of relevant variables from the survey by employment state. We divide the paid employees further into those who do and those who do not enter self-employment between the year of observation and the subsequent year, and report the difference between these two means and its significance level. The paid employees form the estimation sample at risk of entry into self-employment in the hazard rate model; the others are only included in the 
estimation of the equation of selection into being a paid employee. Table A 2 in Appendix A

provides the definitions of the variables.

Table 1: Descriptive statistics by employment status

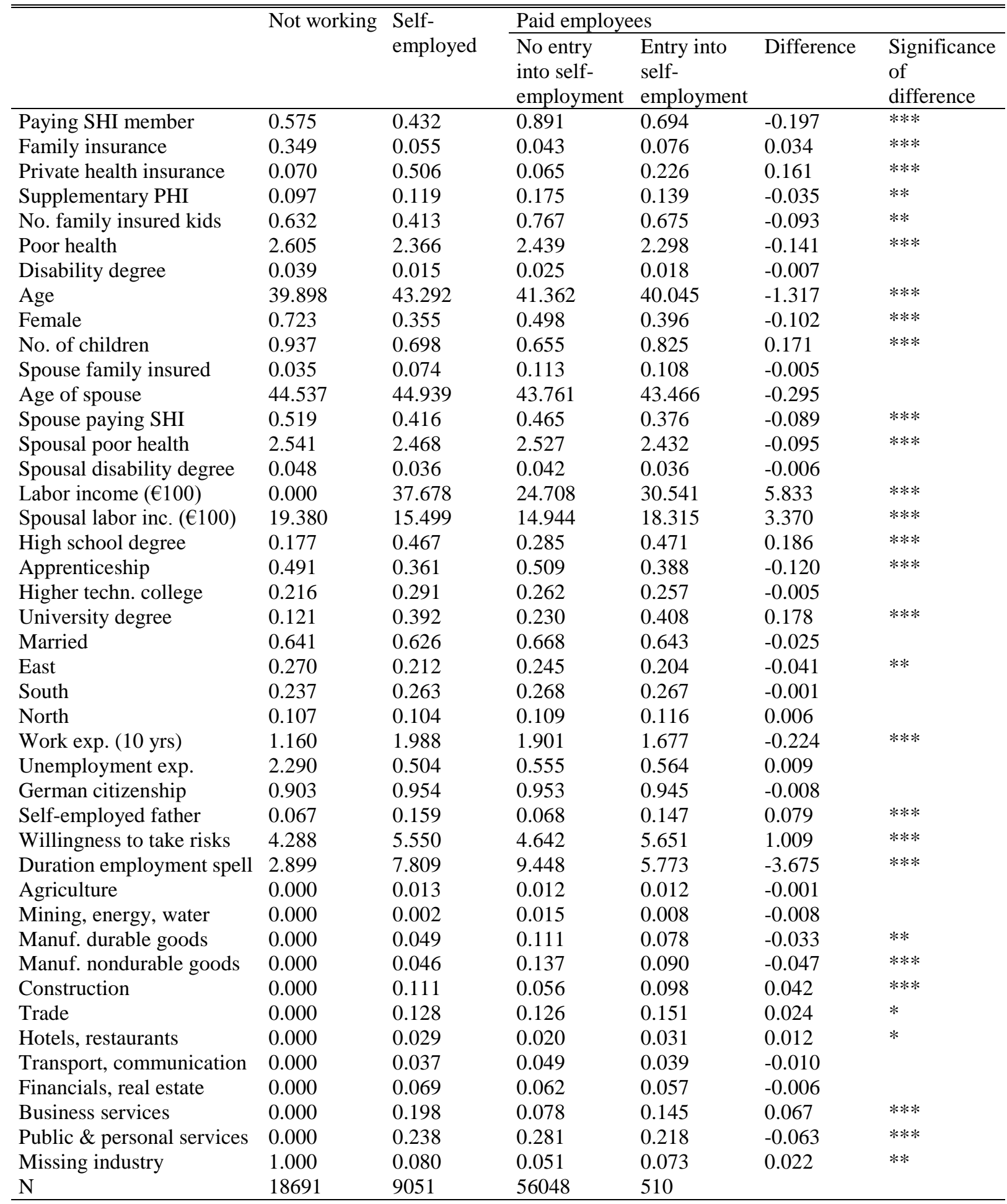

Notes: */*****: Significance of the difference between the means among the employees not entering and those entering into self-employment at the $10 \% / 5 \% / 1 \%$ level.

Source: Authors' calculations based on SOEPv29, 2000-2012. 
Almost $90 \%$ of the paid employees not entering into self-employment are paying members in SHI, $4.3 \%$ are in marginal employment and covered under free family insurance through the spouse's SHI, and 6.5\% have PHI. Among those who make the transition to self-employment within the following year, $22.6 \%$ are already covered under PHI as a paid employee, reflecting the higher mean before-tax labor income of this group (real €3,054 versus $€ 2,471$ per month). The income difference seems to be partly explained by the higher education of those about to venture out on their own: $41 \%$ of them have a university degree, but only $23 \%$ of the other paid employees. The soon-to-be entrepreneurs as well as their spouses are also healthier when looking at the self-assessed measure, but there are no significant differences with regard to the official disability degree. The other variables confirm the known picture. Those who enter into self-employment are more often male, have had a self-employed father, and are more willing to take risk than the other paid employees. They are more often active in the business services and construction industries and less often in manufacturing and public and personal services (the latter category includes employed teachers, for example).

Table 2: Mean simulated health insurance costs

\begin{tabular}{|c|c|c|c|c|}
\hline & \multicolumn{4}{|c|}{ Paid employees } \\
\hline & $\begin{array}{l}\text { No entry into } \\
\text { self-empl. }\end{array}$ & $\begin{array}{l}\text { Entry into } \\
\text { self-empl. }\end{array}$ & Difference & $\begin{array}{l}\text { Significance } \\
\text { of difference }\end{array}$ \\
\hline Actual health insurance costs & 187.890 & 197.221 & 9.332 & $*$ \\
\hline Predicted PHI contributions in SE & 363.455 & 364.702 & 1.247 & \\
\hline Simulated SHI contributions in SE & 379.023 & 386.654 & 7.632 & \\
\hline PHI cheaper choice than SHI & 0.525 & 0.586 & 0.061 & $* * *$ \\
\hline Tax savings in PHI per month & 21.364 & 25.558 & 4.194 & $* *$ \\
\hline Tax savings in SHI per month & 25.556 & 21.999 & -3.557 & $*$ \\
\hline Minimum health insurance costs in SE & 279.955 & 276.760 & -3.195 & \\
\hline Health insurance cost diff. after taxes & 92.065 & 79.539 & -12.527 & $* *$ \\
\hline .. in real terms, divided by 100 & 0.916 & 0.784 & -0.132 & $* *$ \\
\hline .... assuming full shift onto employees & -0.730 & -0.789 & -0.059 & \\
\hline .... SHI plus addit. private health insur. & 0.727 & 0.632 & -0.095 & $*$ \\
\hline .... assuming that $\mathrm{PHI}$ is only option & 1.537 & 1.407 & -0.130 & $*$ \\
\hline
\end{tabular}

Table 2 shows means of simulated variables needed to calculate the HICD for the estimation sample at risk of making the transition from paid to self-employment. We discuss these variables going from top to bottom. The mean current health insurance costs are $€ 188$ for 
employees who stay employees and $€ 9$ more for those who switch to self-employment in the following year, again reflecting the higher average income of the latter group. In the counterfactual case of self-employment, the persons in the sample would pay an average premium of $€ 363$-365 per month if they chose PHI. This variable is predicted using the estimated PHI premium equation and includes premiums for a spouse and children, if these are present and not otherwise covered, as explained in Appendix B. If the person hypothetically entering selfemployment chose voluntary SHI membership, he or she would pay about €16-22 more on average. For $53 \%$ of the paid employees who do not enter self-employment, a PHI policy would be the cheaper choice for the household in case of self-employment; this share is $59 \%$ for those who actually enter. The health insurance costs reported so far are before tax. Since these expenses can partly be deducted from the personal income tax base, the higher costs in case of self-employment lead to tax savings of €21-26 on average per month, both with the PHI and with the SHI. Taking into account the tax savings, each person chooses the lower cost option for the household, PHI or SHI, in case of self-employment. This leads to the hypothetical minimum health insurance costs in case of self-employment after taxes of $€ 277-280$. The mean is lower than the mean of PHI or SHI costs because of the individual choice of the cheaper option. Finally, we subtract the actual current health insurance costs for the household from the hypothetical costs in case of self-employment, both after taxes, and arrive at the nominal HICD. It is $€ 92$ per month for paid employees who do not enter into self-employment, and $€ 80$ per month for those who enter. The difference is significant and may indicate that a higher HICD deters persons from entry into self-employment. The next section explores this much more rigorously using the econometric model which controls for important covariates, state dependence, and selection. For the estimation, we deflate the HICD amount using the Consumer Price Index and divide by $100 .^{17}$

\footnotetext{
${ }^{17}$ The last three rows of Table 2 show alternative measures of the real HICD under different assumptions, which we discuss in Section 6.2.
} 
Figure 1 depicts the distribution of this real HICD in a histogram for all paid employees in the estimation sample. Clearly, the HICD is positive for the most part of the distribution, i.e., health insurance costs for the household increase when a member switches to self-employment because of the loss of the employer's contributions. Insofar, the German health insurance system may constitute a barrier for entry into self-employment. However, there is also an important negative part of the HICD distribution. For example, for a young, healthy and unmarried male the full premium to PHI in case of self-employment can be cheaper than the employee's share to SHI contributions. Thus, the health insurance system may provide incentives to enter self-employment for persons whose income is not high enough to opt out of the SHI as a paid employee. For them, self-employment lifts the barrier to PHI.

\section{Figure 1: Histogram of the simulated health insurance cost differential}

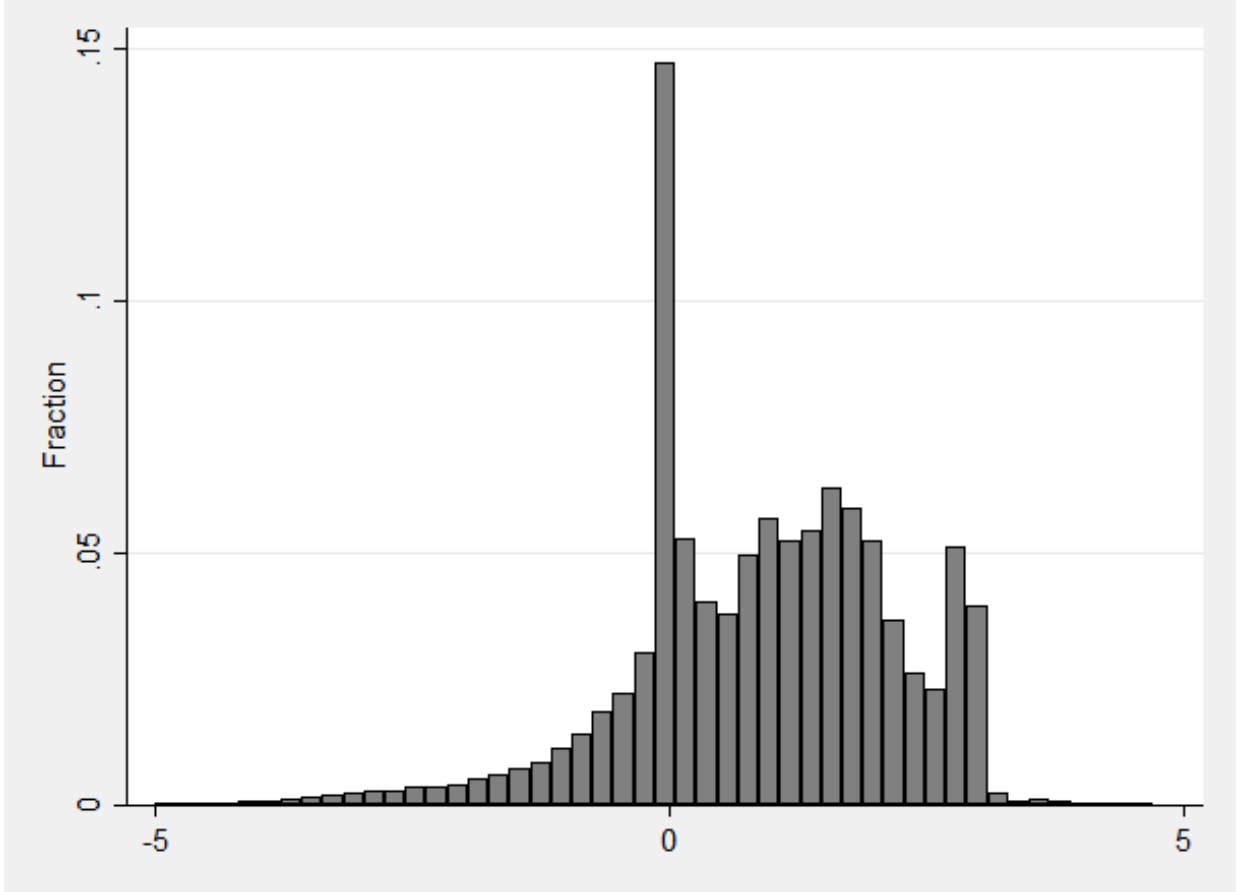

Note: The histogram shows the distribution of the simulated differential in the monthly health insurance costs between the alternatives of self-employment and regular employment in real 100 euros of 2005. Here, the incidence assumption is that the burden of the health insurance costs is shared between employers and employees according to the statutory division, i.e., roughly by half.

Source: Authors' calculations based on SOEPv29, 2000-2012.

The histogram further shows that there is a bunching at zero, which indicates that for almost $15 \%$ of the individuals in the sample, health insurance costs for the household would not change 
at all if they switched to self-employment. For example, this is the case for persons with income below the marginal employment threshold who are insured under free family insurance through their spouse's SHI membership, because they can keep their family insurance in selfemployment. Another bunching occurs at the right side of the distribution with a high HICD. Again, marginal employment plays a role here, because a marginally employed person who cannot be covered under family insurance through a spouse or parent is covered under SHI with zero employee's contributions, but not as a low-income self-employed person. In the latter situation, the person has to pay the full income-independent PHI premium, or as a voluntary SHI member, the lower limit of income for the assessment of SHI contributions for the selfemployed applies. In both cases, costs increase drastically in comparison to free SHI coverage, and the health insurance system constitutes a significant barrier for self-employment.

\section{Econometric results}

\subsection{The effect of the health insurance cost differential}

Table 3 provides the main results from estimating the hazard rate model of transition from paid employment into self-employment in equation (2). The table shows probit coefficients and the average marginal effect of the key explanatory variable, the health insurance cost differential (HICD) between counter-factual self-employment and paid employment. The standard errors are robust to heteroscedasticity and clustering at the individual level; those of the marginal effects are obtained using the Delta Method. Average marginal effects of further variables appear in Table A 3 in Appendix A. The estimated probit coefficients from the equation of selection into the estimation sample of paid employees are given in Table A 4 and show that most of the variables with exclusion restriction (at the bottom of the table) are highly significant. The correlation between the error terms of the selection and the transition equations $\rho$ turns out to be significantly different from zero only when restricting the sample to men. 
Table 3: Self-employment entry probability conditional on health insurance cost differential

\begin{tabular}{|c|c|c|c|c|c|c|}
\hline & $\begin{array}{l}\text { (1) Full } \\
\text { sample }\end{array}$ & (2) Men & (3) Women & $\begin{array}{l}\text { (4) Income } \\
\text { splines }\end{array}$ & $\begin{array}{l}\text { (5) Alterna- } \\
\text { tive health } \\
\text { measure }\end{array}$ & $\begin{array}{l}(6) \text { Unob- } \\
\text { served hete- } \\
\text { rogeneity }\end{array}$ \\
\hline HI cost diff. $(€ 100)$ & $\begin{array}{l}-0.0780 * * * \\
(0.0185)\end{array}$ & $\begin{array}{l}-0.1050 * * * \\
(0.0236)\end{array}$ & $\begin{array}{l}-0.0170 \\
(0.0289)\end{array}$ & $\begin{array}{l}-0.0797 * * * \\
(0.0176)\end{array}$ & $\begin{array}{l}-0.0796 * * * \\
(0.0184)\end{array}$ & $\begin{array}{l}-0.1051^{* * * *} \\
(0.0311)\end{array}$ \\
\hline Marginal effect & $\begin{array}{l}-0.0038 * * * \\
(0.0010)\end{array}$ & $\begin{array}{l}-0.0068 * * * \\
(0.0016)\end{array}$ & $\begin{array}{l}-0.0007 \\
(0.0012)\end{array}$ & $\begin{array}{l}-0.0037 * * * \\
(0.0009)\end{array}$ & $\begin{array}{l}-0.0039 * * * \\
(0.0010)\end{array}$ & $\begin{array}{l}-0.0027 * \\
(0.0016)\end{array}$ \\
\hline Poor health & $\begin{array}{l}-0.0484 * \\
(0.0261)\end{array}$ & $\begin{array}{l}-0.0822 * * \\
(0.0355)\end{array}$ & $\begin{array}{l}-0.0093 \\
(0.0381)\end{array}$ & $\begin{array}{l}-0.0463 * \\
(0.0260)\end{array}$ & & $\begin{array}{l}-0.0835^{*} \\
(0.0443)\end{array}$ \\
\hline Disability degree & & & & & $\begin{array}{l}-0.4007 * * \\
(0.2006)\end{array}$ & \\
\hline Age & $\begin{array}{l}-0.0123 * * \\
(0.0061)\end{array}$ & $\begin{array}{l}-0.0065 \\
(0.0104)\end{array}$ & $\begin{array}{l}-0.0119 \\
(0.0079)\end{array}$ & $\begin{array}{l}-0.0110^{*} \\
(0.0062)\end{array}$ & $\begin{array}{l}-0.0126^{* * *} \\
(0.0062)\end{array}$ & $\begin{array}{l}-0.0234 * * \\
(0.0099)\end{array}$ \\
\hline Supplementary PHI & $\begin{array}{l}-0.0058 \\
(0.0570)\end{array}$ & $\begin{array}{l}0.0342 \\
(0.0806)\end{array}$ & $\begin{array}{l}-0.0094 \\
(0.0790)\end{array}$ & $\begin{array}{l}-0.0096 \\
(0.0566)\end{array}$ & $\begin{array}{l}-0.0067 \\
(0.0569)\end{array}$ & $\begin{array}{l}-0.0459 \\
(0.0997)\end{array}$ \\
\hline Age of spouse & $\begin{array}{l}0.0005 \\
(0.0006)\end{array}$ & $\begin{array}{l}0.0130 * * \\
(0.0061)\end{array}$ & $\begin{array}{l}0.0004 \\
(0.0006)\end{array}$ & $\begin{array}{l}0.0005 \\
(0.0005)\end{array}$ & $\begin{array}{l}0.0004 \\
(0.0006)\end{array}$ & $\begin{array}{l}0.0008 \\
(0.0006)\end{array}$ \\
\hline Spousal poor health & $\begin{array}{l}-0.0456 \\
(0.0298)\end{array}$ & $\begin{array}{l}-0.0413 \\
(0.0408)\end{array}$ & $\begin{array}{l}-0.0490 \\
(0.0448)\end{array}$ & $\begin{array}{l}-0.0451 \\
(0.0295)\end{array}$ & & $\begin{array}{l}-0.0702 \\
(0.0500)\end{array}$ \\
\hline Spousal disability deg. & & & & & $\begin{array}{l}0.0454 \\
(0.2432)\end{array}$ & \\
\hline $\begin{array}{l}\text { Spousal labor inc. } \\
(€ 100) \\
\text { Female }\end{array}$ & $\begin{array}{l}0.0006 \\
(0.0008) \\
-0.4598 * * * \\
(0.0630)\end{array}$ & $\begin{array}{l}-0.0027 \\
(0.0024)\end{array}$ & $\begin{array}{l}0.0017 * * \\
(0.0008)\end{array}$ & $\begin{array}{l}0.0006 \\
(0.0008) \\
-0.4676^{* * *} \\
(0.0635)\end{array}$ & $\begin{array}{l}0.0007 \\
(0.0008) \\
-0.4705 * * * \\
(0.0633)\end{array}$ & $\begin{array}{l}0.0013 \\
(0.0012) \\
-0.8268 * * * \\
(0.1246)\end{array}$ \\
\hline No. of children & $\begin{array}{l}0.1247 * * * \\
(0.0287)\end{array}$ & $\begin{array}{l}0.1175 * * * \\
(0.0327)\end{array}$ & $\begin{array}{l}-0.0387 \\
(0.0437)\end{array}$ & $\begin{array}{l}0.1248 * * * \\
(0.0289)\end{array}$ & $\begin{array}{l}0.1290 * * * \\
(0.0284)\end{array}$ & $\begin{array}{l}0.1996 * * * \\
(0.0538)\end{array}$ \\
\hline Female $*$ no. of childr. & $\begin{array}{l}-0.1756 * * * \\
(0.0473)\end{array}$ & & & $\begin{array}{l}-0.1732 * * * \\
(0.0468)\end{array}$ & $\begin{array}{l}-0.1776 * * * \\
(0.0471)\end{array}$ & $\begin{array}{l}-0.2268 * * * \\
(0.0831)\end{array}$ \\
\hline $\begin{array}{l}\text { Real wage inc. } \\
(€ 10,000)\end{array}$ & $\begin{array}{l}-8.7656 * * * \\
(0.5332)\end{array}$ & $\begin{array}{l}-9.4864 * * * \\
(0.6503)\end{array}$ & $\begin{array}{l}-15.0253 * * * \\
(1.6953)\end{array}$ & & $\begin{array}{l}-8.8006 * * * \\
(0.5369)\end{array}$ & $\begin{array}{l}-15.0101 * * * \\
(1.2460)\end{array}$ \\
\hline Real wage inc. squared & $\begin{array}{l}9.7299 * * * \\
(1.0963)\end{array}$ & $\begin{array}{l}10.0885^{* * * *} \\
(1.1698)\end{array}$ & $\begin{array}{l}43.1929 * * * \\
(9.3096)\end{array}$ & & $\begin{array}{l}9.7741 * * * \\
(1.0999)\end{array}$ & $\begin{array}{l}16.7577 * * * \\
(2.0724)\end{array}$ \\
\hline Real wage inc. cubed & $\begin{array}{l}-3.2599 * * * \\
(0.5898)\end{array}$ & $\begin{array}{l}-3.3009 * * * \\
(0.5946)\end{array}$ & $\begin{array}{l}-42.2009 * * * \\
(14.2165)\end{array}$ & & $\begin{array}{l}-3.2722 * * * \\
(0.5910)\end{array}$ & $\begin{array}{l}-5.5810 * * * \\
(1.0308)\end{array}$ \\
\hline Real wage inc. ${ }^{4}$ & $\begin{array}{l}0.2372 * * * \\
(0.0486)\end{array}$ & $\begin{array}{l}0.2384 * * * \\
(0.0485)\end{array}$ & $\begin{array}{l}9.2632 * * * \\
(3.5309)\end{array}$ & & $\begin{array}{l}0.2380 * * * \\
(0.0487)\end{array}$ & $\begin{array}{l}0.4051 * * * \\
(0.0840)\end{array}$ \\
\hline Real wage inc. spline 1 & & & & $\begin{array}{l}-6.0311 * * * \\
(0.3350)\end{array}$ & & \\
\hline Real wage inc. spline 2 & & & & $\begin{array}{l}1.5228 * * * \\
(0.4200)\end{array}$ & & \\
\hline Real wage inc. spline 3 & & & & $\begin{array}{l}-0.5243 \\
(0.9686)\end{array}$ & & \\
\hline Real wage inc. spline 4 & & & & $\begin{array}{l}0.5213 \\
(1.5115)\end{array}$ & & \\
\hline Real wage inc. spline 5 & & & & $\begin{array}{l}0.0128 \\
(0.1675)\end{array}$ & & \\
\hline High school degree & $\begin{array}{l}0.2174 * * * \\
(0.0589)\end{array}$ & $\begin{array}{l}0.1302 \\
(0.0871)\end{array}$ & $\begin{array}{l}0.2847 * * * \\
(0.0835)\end{array}$ & $\begin{array}{l}0.2289 * * * \\
(0.0586)\end{array}$ & $\begin{array}{l}0.2201 * * * \\
(0.0586)\end{array}$ & $\begin{array}{l}0.4400 * * * \\
(0.1137)\end{array}$ \\
\hline Apprenticeship & $\begin{array}{l}0.0248 \\
(0.0571)\end{array}$ & $\begin{array}{l}0.1757 * * \\
(0.0813)\end{array}$ & $\begin{array}{l}-0.1602 * * \\
(0.0775)\end{array}$ & $\begin{array}{l}0.0216 \\
(0.0570)\end{array}$ & $\begin{array}{l}0.0215 \\
(0.0564)\end{array}$ & $\begin{array}{l}0.0918 \\
(0.1034)\end{array}$ \\
\hline Higher techn. college & $\begin{array}{l}0.1412 * * \\
(0.0613)\end{array}$ & $\begin{array}{l}0.2656 * * * \\
(0.0893)\end{array}$ & $\begin{array}{l}0.0174 \\
(0.0813)\end{array}$ & $\begin{array}{l}0.1353 * * \\
(0.0614)\end{array}$ & $\begin{array}{l}0.1390 * * \\
(0.0605)\end{array}$ & $\begin{array}{l}0.3154 * * * \\
(0.1157)\end{array}$ \\
\hline University degree & $\begin{array}{l}0.5691 * * * \\
(0.0631)\end{array}$ & $\begin{array}{l}0.5895 * * * \\
(0.0894)\end{array}$ & $\begin{array}{l}0.4594 * * * \\
(0.0927)\end{array}$ & $\begin{array}{l}0.5654 * * * \\
(0.0633)\end{array}$ & $\begin{array}{l}0.5722 * * * \\
(0.0627)\end{array}$ & $\begin{array}{l}1.0358 * * * \\
(0.1294)\end{array}$ \\
\hline Married & $\begin{array}{l}-0.0840 \\
(0.0559)\end{array}$ & $\begin{array}{l}0.0913 \\
(0.0855)\end{array}$ & $\begin{array}{l}-0.1196 \\
(0.0857)\end{array}$ & $\begin{array}{l}-0.0708 \\
(0.0555)\end{array}$ & $\begin{array}{l}-0.0895 \\
(0.0559)\end{array}$ & $\begin{array}{l}-0.1068 \\
(0.0987)\end{array}$ \\
\hline East & $\begin{array}{l}-0.1766^{* * * *} \\
(0.0599)\end{array}$ & $\begin{array}{l}-0.2822 * * * \\
(0.0766)\end{array}$ & $\begin{array}{l}-0.0003 \\
(0.0952)\end{array}$ & $\begin{array}{l}-0.2105 * * * \\
(0.0599)\end{array}$ & $\begin{array}{l}-0.1728 * * * \\
(0.0599)\end{array}$ & $\begin{array}{l}-0.3093 * * * \\
(0.1122)\end{array}$ \\
\hline
\end{tabular}


Table 3 continued

\begin{tabular}{|c|c|c|c|c|c|c|}
\hline & $\begin{array}{l}\text { (1) Full } \\
\text { sample }\end{array}$ & (2) Men & (3) Women & $\begin{array}{l}\text { (4) Income } \\
\text { splines }\end{array}$ & $\begin{array}{l}\text { (5) Alt. } \\
\text { health } \\
\text { measure }\end{array}$ & $\begin{array}{l}\text { (6) Unob- } \\
\text { served hete- } \\
\text { rogeneity }\end{array}$ \\
\hline South & $\begin{array}{l}0.0075 \\
(0.0518)\end{array}$ & $\begin{array}{l}-0.0207 \\
(0.0695)\end{array}$ & $\begin{array}{l}0.0620 \\
(0.0799)\end{array}$ & $\begin{array}{l}0.0032 \\
(0.0512)\end{array}$ & $\begin{array}{l}0.0147 \\
(0.0521)\end{array}$ & $\begin{array}{l}-0.0028 \\
(0.0971)\end{array}$ \\
\hline North & $\begin{array}{l}0.0206 \\
(0.0725)\end{array}$ & $\begin{array}{l}-0.0213 \\
(0.0979)\end{array}$ & $\begin{array}{l}0.0780 \\
(0.1053)\end{array}$ & $\begin{array}{l}0.0173 \\
(0.0721)\end{array}$ & $\begin{array}{l}0.0198 \\
(0.0718)\end{array}$ & $\begin{array}{l}0.0419 \\
(0.1337)\end{array}$ \\
\hline Work exp. (10 yrs) & $\begin{array}{l}0.3248 * * \\
(0.1283)\end{array}$ & $\begin{array}{l}0.3882 * * \\
(0.1645)\end{array}$ & $\begin{array}{l}0.2279 \\
(0.1927)\end{array}$ & $\begin{array}{l}0.3043 * * \\
(0.1288)\end{array}$ & $\begin{array}{l}0.3231 * * \\
(0.1295)\end{array}$ & $\begin{array}{l}0.6761 * * * \\
(0.2004)\end{array}$ \\
\hline Work exp. squared & $\begin{array}{l}-0.0418^{*} \\
(0.0254)\end{array}$ & $\begin{array}{l}-0.0817 * * \\
(0.0332)\end{array}$ & $\begin{array}{l}-0.0281 \\
(0.0407)\end{array}$ & $\begin{array}{l}-0.0395 \\
(0.0254)\end{array}$ & $\begin{array}{l}-0.0422 * \\
(0.0256)\end{array}$ & $\begin{array}{l}-0.0973 * * \\
(0.0427)\end{array}$ \\
\hline Unemployment exp. & $\begin{array}{l}-0.0346 \\
(0.0380)\end{array}$ & $\begin{array}{l}-0.0710 * * \\
(0.0339)\end{array}$ & $\begin{array}{l}0.1027 * \\
(0.0558)\end{array}$ & $\begin{array}{l}-0.0413 \\
(0.0331)\end{array}$ & $\begin{array}{l}-0.0418 \\
(0.0346)\end{array}$ & $\begin{array}{l}-0.0612 \\
(0.0672)\end{array}$ \\
\hline Unempl. exp. squared & $\begin{array}{l}-0.0006 \\
(0.0043)\end{array}$ & $\begin{array}{l}0.0021 \\
(0.0015)\end{array}$ & $\begin{array}{l}-0.0206 * * * \\
(0.0070)\end{array}$ & $\begin{array}{l}0.0002 \\
(0.0033)\end{array}$ & $\begin{array}{l}0.0001 \\
(0.0036)\end{array}$ & $\begin{array}{l}-0.0023 \\
(0.0082)\end{array}$ \\
\hline German citizenship & $\begin{array}{l}-0.0135 \\
(0.0996)\end{array}$ & $\begin{array}{l}-0.0285 \\
(0.1347)\end{array}$ & $\begin{array}{l}0.0113 \\
(0.1475)\end{array}$ & $\begin{array}{l}0.0038 \\
(0.1018)\end{array}$ & $\begin{array}{l}-0.0119 \\
(0.0991)\end{array}$ & $\begin{array}{l}0.0425 \\
(0.1785)\end{array}$ \\
\hline Self-employed father & $\begin{array}{l}0.2734 * * * \\
(0.0676)\end{array}$ & $\begin{array}{l}0.3314 * * * \\
(0.0920)\end{array}$ & $\begin{array}{l}0.2495 * * * \\
(0.0929)\end{array}$ & $\begin{array}{l}0.2625 * * * \\
(0.0683)\end{array}$ & $\begin{array}{l}0.2687 * * * \\
(0.0680)\end{array}$ & $\begin{array}{l}0.4733 * * * \\
(0.1302)\end{array}$ \\
\hline Willingn. to take risks & $\begin{array}{l}0.0766 * * * \\
(0.0107)\end{array}$ & $\begin{array}{l}0.0857 * * * \\
(0.0153)\end{array}$ & $\begin{array}{l}0.0639 * * * \\
(0.0142)\end{array}$ & $\begin{array}{l}0.0763 * * * \\
(0.0107)\end{array}$ & $\begin{array}{l}0.0770 * * * \\
(0.0107)\end{array}$ & $\begin{array}{l}0.1282 * * * \\
(0.0189)\end{array}$ \\
\hline 11 industry dummies & $p=0.0306$ & $p=0.1405$ & $p<0.0001$ & $p=0.0314$ & $p=0.0376$ & $p=0.0341$ \\
\hline 12 duration dummies & $p<0.0001$ & $p=0.0001$ & $p=0.0002$ & $p<0.0001$ & $p<0.0001$ & $p=0.0179$ \\
\hline Full set year dummies & $p<0.0001$ & $p<0.0001$ & $p<0.0001$ & $p<0.0001$ & $p<0.0001$ & $p=0.0110$ \\
\hline Constant & $\begin{array}{l}1.8271 * * * \\
(0.0938)\end{array}$ & $\begin{array}{l}2.0987 * * * \\
(0.1849)\end{array}$ & $\begin{array}{l}1.7326 * * * \\
(0.1083)\end{array}$ & $\begin{array}{l}1.8272 * * * \\
(0.0938)\end{array}$ & $\begin{array}{l}1.8139 * * * \\
(0.0899)\end{array}$ & $\begin{array}{l}-2.1436 * * * \\
(0.3923)\end{array}$ \\
\hline$\rho$ & -0.0758 & -0.1853 & -0.1010 & -0.0656 & -0.0735 & \\
\hline $\begin{array}{l}\text { Test of } \rho=0: p \text {-value } \\
\text { Log var. random effect }\end{array}$ & 0.4714 & 0.0108 & 0.4556 & 0.5456 & 0.4873 & $\begin{array}{l}0.6769 * * * \\
(0.1673)\end{array}$ \\
\hline Log likelihood & $-44,843.16$ & $-21,359.75$ & $-22,970.24$ & $-44,880.51$ & $-44,850.93$ & $-2,083.6724$ \\
\hline Observations & 84,300 & 39,462 & 44,838 & 84,300 & 84,265 & \\
\hline Selected observations & 56,558 & 28,451 & 28,107 & 56,558 & 56,538 & 56,558 \\
\hline Mean outcome & 0.0111 & 0.0128 & 0.0095 & 0.0111 & 0.0111 & 0.0111 \\
\hline
\end{tabular}

Notes: Discrete time hazard rate model specified as a probit model with selection correction. This table shows probit coefficients of the equation modelling the transition to self-employment; the estimated selection equation is shown in Table A 4 in the Appendix. Average marginal effects of the health cost differential are also shown; those of further variables appear in Table A 3. The dependent variable is a binary indicator of entry into self-employment between years $t$ and $t+1$. Standard errors are robust to heteroscedasticity and clustering at the individual level. $\rho$ is the selection correction term. In the rows referring to sets of dummy variables, the $p$-values derive from tests of joint significance. Definitions of the variables are displayed in Table A 2.

$* / * * / * * *$ : Significance of the coefficient at the $10 \% / 5 \% / 1 \%$ level.

Source: Authors' calculations based on SOEPv29, 2000-2012.

Column (1) of Table 3 shows the main specification for the full sample. The HICD has a negative effect on the probability of entry into self-employment significant at the $1 \%$-level. As the HICD is coded in units of 100 euro, increasing the additional cost in case of selfemployment by 100 euro (the standard deviation of the HICD among paid employees is 120 euro) decreases the entry probability by 0.38 percentage points on average. This is $34 \%$ of the annual transition rate from paid employment to self-employment of $1.11 \%$, as indicated at the 
bottom of the table. This indicates that the decision of paid employees to switch to selfemployment is strongly influenced by the additional costs (or cost savings) for health insurance for the household.

The effect is even stronger for men with a relative effect of $54 \%$ of the entry rate. For women, the effect has the same sign, but is smaller and insignificant. Apparently, women do not respond as strongly to monetary incentives provided by the health insurance system as men when considering self-employment. Reasons may be the traditional male role of being the main bread-earner in Germany, whereas for women, non-pecuniary aspects of self-employment such as the flexibility of time and location of work may be more important on average (Georgellis and Wall, 2005).

As mentioned before, it is important to control for possibly non-linear effects of the wage income of the paid employees, because these are correlated with the HICD and may have a direct effect on self-employment choice. Going back to the full sample, in column (4), we replace the fourth order polynomial of income we use in the main specification by a spline function with five splines of equal width within the interval from zero to $€ 20,000$ per month, where the highest spline also includes observations with higher income. We observe that the coefficient and marginal effect of the HICD remains almost unchanged, indicating that the estimates are not sensitive to the functional form assumption with regard to income.

Persons with poorer health are less likely to enter self-employment, even after controlling for the HICD, which accounts for the higher costs of PHI implied by the poorer health. In the main estimation based on the full sample in column (1), a deterioration of health by one point on the five point scale of self-assessed general health decreases the entry probability by 0.25 percentage points on average in the sample (average marginal effect in Table A 3), i.e. $23 \%$ of the annual transition rate; the standard deviation of the health measure among all employees is 0.82. Similarly, Parker and Rougier (2007) report that older workers with poor health are less likely to move into self-employment in Britain. Self-employment is associated with longer work 
hours than paid employment and considerable strains (Lewin-Epstein and Yuchtman-Yaar, 1991), which may deter less healthy persons from this choice, in addition to the implications for health insurance costs discussed. The partial effect of spousal poor health is not significant when controlling for the HICD in our estimations. In Section 6.3, we show that omitting the HICD leads to a significant negative coefficient of poor spousal health. Thus, spousal health affects the entry decision, but exclusively through the higher PHI costs implied.

In column (5) of Table 3, we explore the official degree of disability as an alternative, more objective health measure (see Section 5.1), and again find a significantly negative partial effect of poorer health. A higher disability degree by ten percentage points decreases the entry probability by 0.2 percentage points (Table A 3 ) or $18 \%$ of the entry rate. ${ }^{18}$ Similarly, higher age decreases the likelihood of the transition, ceteris paribus. However, work experience has a positive effect at decreasing marginal rates.

In further robustness checks, we allow for unobserved heterogeneity between individuals. In column (6) of Table 3, we consider an individual-specific random effect with a normal distribution. We do not control for selection in this estimation, which seems justified considering that the selection term turned out insignificant in the baseline estimation. The variance of the individual random effect is significantly different from zero. The estimated probit coefficient of the HICD becomes somewhat larger, but not significantly different from the point estimate in column (1). The marginal effect, evaluated at the mean values of the explanatory variables and the random effect, is closer to zero than in the baseline estimation, but not significantly different. We also estimate complementary log-log models with an arbitrary discrete distribution of the individual random effect (not reported in the table). We achieve convergence with two mass points based on a quasi-Hessian convergence criterion, but

\footnotetext{
${ }^{18}$ For the UK, Jones and Latreille (2011) report that nonwork-limited disabled persons are less likely to be selfemployed than the nondisabled, whereas work-limited disabled men are more likely to be self-employed, which could be explained by the greater flexibility self-employment offers in terms of times, hours, and locations.
} 
the mass points are not significantly different from each other. We calculate the marginal effects for the two latent types at the mean values of the explanatory variables, and then the average weighted by the estimated type probabilities. The point estimate is -0.0023 with a standard error of 0.0009 , which again is not significantly different from the baseline estimate. We conclude that the results are not very sensitive to the modelling of unobserved heterogeneity.

In all specifications, the control variables confirm expectations. Women have a smaller self-employment entry rate (cf. Caliendo et al., 2014), especially if children are present in the household. The transition probability increases with university education, a self-employed father (cf. Dunn and Holtz-Eakin, 2000), and a higher willingness to take risk in the year before the transition (cf. Caliendo et al., 2009).

\subsection{Different assumptions about the health insurance cost differential}

In this section we explore the sensitivity of the results with respect to the assumptions taken in order to calculate the HICD. In the main estimations, we assume that the incidence of the burden of the health insurance costs, as perceived by the paid employees when they consider switching to self-employment, equals the statutory incidence, i.e., employers and employees bear roughly half of the contributions. However, it is possible that employers are able to shift the burden onto employees by paying lower wages, or the other way round. Using data from Eurostat on labor costs, Ooghe et al. (2003) estimate that more than half of the burden of social security contributions are borne by the employees in Europe. Gruber (2000) concludes from a literature review that the costs of health insurance are even fully shifted onto the employees.

In the first column of Table 4, we therefore assume that the total SHI contributions and PHI premiums, i.e., both the statutory employee's and employer's shares, are effectively borne by the employees. This reduces the average real HICD between the alternatives of selfemployment and paid employment from 91.6 to -73.0 euro for the paid employees who do not enter self-employment, and from 78.4 to -78.9 euro for those who make the transition (see Table 
2). In the baseline assumption, the step into self-employment on average implies higher health insurance costs, because the nascent entrepreneur loses the employer's contributions. If the employer's contributions are fully shifted onto the employer anyway, the situation becomes relatively cheaper in self-employment on average, because self-employment opens up the PHI option, total costs of which are often lower. Despite the drastic shift in the distribution of the HICD, the sign and significance level of its estimated coefficient remain the same as in the main estimation in the first column of Table 3. The point estimate of the average marginal effect is larger in absolute terms here, but the confidence intervals of the two estimates overlap, indicating that these are not significantly different.

In the second column of Table 4, we return to the baseline assumption regarding incidence, but re-calculate the HICD by adding the cost of supplementary PHI to the health insurance costs associated with SHI. We use the mean of the costs those employees in the sample who actually have supplementary PHI report paying for it. As discussed in Section 3.1, this makes the benefits and services of the SHI and PHI options more comparable. Again, this decreases the average HICD and makes self-employment look more attractive (Table 2). The estimated effect of the HICD is very similar to the main estimation.

Finally, we assess the robustness with respect to the assumption that the choice between voluntary SHI and PHI in case of self-employment is determined by the lowest total cost for the household (if both options are available). Instead, in the third column of Table 4, we assume that everybody considers the HICD associated with PHI in case of self-employment. The estimated effect of the HICD becomes somewhat larger in absolute terms than in the main estimation, but not significantly different. In summary, we conclude that the results are robust to the assumptions taken for the calculation of the HICD. 
Table 4: Self-employment entry probability with varying assumptions about the health insurance cost differential

\begin{tabular}{|c|c|c|c|}
\hline & HICD with full shift & HICD with suppl. PHI & HICD with PHI only \\
\hline HICD with full shift $(€ 100)$ & $\begin{array}{l}-0.1415 * * * \\
(0.0168)\end{array}$ & & \\
\hline HICD with suppl. PHI (€100) & & $\begin{array}{l}-0.0795 * * * \\
(0.0183)\end{array}$ & \\
\hline HICD with PHI only $(€ 100)$ & & & $\begin{array}{l}-0.1025 * * * \\
(0.0170)\end{array}$ \\
\hline Marginal effect & $\begin{array}{l}-0.0068 * * * \\
(0.0009)\end{array}$ & $\begin{array}{l}-0.0039 * * * \\
(0.0009)\end{array}$ & $\begin{array}{l}-0.0051 * * * \\
(0.0009)\end{array}$ \\
\hline Poor health & $\begin{array}{l}-0.0383 \\
(0.0260)\end{array}$ & $\begin{array}{l}-0.0474 * \\
(0.0262)\end{array}$ & $\begin{array}{l}-0.0348 \\
(0.0260)\end{array}$ \\
\hline Age & $\begin{array}{l}-0.0113^{*} \\
(0.0062)\end{array}$ & $\begin{array}{l}-0.0119^{*} \\
(0.0061)\end{array}$ & $\begin{array}{l}-0.0073 \\
(0.0060)\end{array}$ \\
\hline Supplementary PHI & $\begin{array}{l}0.0089 \\
(0.0566)\end{array}$ & $\begin{array}{l}-0.0081 \\
(0.0569)\end{array}$ & $\begin{array}{l}0.0027 \\
(0.0563)\end{array}$ \\
\hline Age of spouse & $\begin{array}{l}0.0005 \\
(0.0006)\end{array}$ & $\begin{array}{l}0.0005 \\
(0.0006)\end{array}$ & $\begin{array}{l}0.0005 \\
(0.0006)\end{array}$ \\
\hline Spousal poor health & $\begin{array}{l}-0.0426 \\
(0.0305)\end{array}$ & $\begin{array}{l}-0.0455 \\
(0.0298)\end{array}$ & $\begin{array}{l}-0.0366 \\
(0.0295)\end{array}$ \\
\hline Spousal labor inc. $(€ 100)$ & $\begin{array}{l}0.0005 \\
(0.0008)\end{array}$ & $\begin{array}{l}0.0006 \\
(0.0008)\end{array}$ & $\begin{array}{l}0.0001 \\
(0.0009)\end{array}$ \\
\hline Female & $\begin{array}{l}-0.3956 * * * \\
(0.0621)\end{array}$ & $\begin{array}{l}-0.4527 * * * \\
(0.0630)\end{array}$ & $\begin{array}{l}-0.4174 * * * \\
(0.0627)\end{array}$ \\
\hline No. of children & $\begin{array}{l}0.1308 * * * \\
(0.0308)\end{array}$ & $\begin{array}{l}0.1283 * * * \\
(0.0288)\end{array}$ & $\begin{array}{l}0.1593 * * * \\
(0.0311)\end{array}$ \\
\hline Female $*$ no. of children & $\begin{array}{l}-0.1711 * * * \\
(0.0479)\end{array}$ & $\begin{array}{l}-0.1761 * * * \\
(0.0472)\end{array}$ & $\begin{array}{l}-0.1731 * * * \\
(0.0470)\end{array}$ \\
\hline Further control variables & Yes & Yes & Yes \\
\hline$\rho$ & -0.0823 & -0.0737 & -0.0845 \\
\hline Test of $\rho=0: p$-value & 0.4317 & 0.4855 & 0.4085 \\
\hline Log likelihood & $-44,802.38$ & $-44,842.51$ & $-45,065.27$ \\
\hline Observations & 84,300 & 84,300 & 84,631 \\
\hline Selected observations & 56,558 & 56,558 & 56,889 \\
\hline Mean outcome & 0.0111 & 0.0111 & 0.0111 \\
\hline \multicolumn{4}{|c|}{$\begin{array}{l}\text { Notes: Discrete time hazard rate model specified as a probit model with selection correction. The table shows } \\
\text { probit coefficients of selected variables in the equation modelling the transition to self-employment; the estimated } \\
\text { selection equation and the coefficients of the other control variables, which are the same as in Table } 3 \text {, are available } \\
\text { from the authors on request. Average marginal effects of the health cost differential are also shown. The dependent } \\
\text { variable is a binary indicator of entry into self-employment between years } t \text { and } t+1 \text {. Standard errors are robust to } \\
\text { heteroscedasticity and clustering at the individual level. } \rho \text { is the selection correction term. } \\
* / * * / * * * \text { : Significance of the coefficient at the } 10 \% / 5 \% / 1 \% \text { level. }\end{array}$} \\
\hline
\end{tabular}

\subsection{The effect of health and the family situation on entry into entrepreneurship}

We have discussed which characteristics of household members influence the HICD, and we have estimated that the HICD has a sizable and significant effect on the probability of transition from paid employment to self-employment. In this section, we take a step back and re-estimate the same hazard rate model, but exclude the HICD and directly include factors that determine the HICD amount instead. This approach is comparable to the extant literature for the USA, 
which does not calculate a HICD (Holtz-Eakin et al., 1996; Wellington, 2001; Zissimopoulos and Karoly, 2007; Fairlie et al., 2011). Table 5 shows the probit coefficients for the full sample and separately for men and women; average marginal effects of the most interesting variables appear in the rightmost three columns of Table A 3 in Appendix A.

In these estimations, poorer health strongly decreases the probability of entry into selfemployment for men. A one point deterioration on the five point scale (std dev.: 0.82) decreases the entry probability by 0.59 percentage points on average (Table A 3), i.e. $46 \%$ of the mean entry rate. In this specification, this is the combined effect of the expected additional PHI premiums and any other deterring effect poor health has on self-employment. Poorer health of the spouse also decreases the entry probability in the pooled sample and for men in these specifications omitting the HICD. The finding that spousal health becomes insignificant when including the HICD indicates that the deterring effect of poor spousal health works through increasing health insurance costs in case of self-employment, as mentioned before.

A paid employee currently covered under and paying for SHI, i.e., not in marginal employment, is less likely to enter self-employment than somebody who already has PHI. While the latter can keep the current PHI contract without a new health assessment when stepping into self-employment, the former needs to give up SHI in order to switch to PHI, which requires a new health assessment. This constitutes a barrier comparable to entrepreneurship lock in the USA, where employees are reluctant to lose their employer provided health insurance. The alternative of remaining in voluntary SHI may be too expensive especially for individuals with higher income, since the employer's contributions are lost. Paid employees with marginal employment who are covered by free family insurance through their spouse or parent are even more hesitant to venture out on their own. Although they may keep their family insurance if their income remains below the marginal employment threshold, they may fear to lose family insurance should their income exceed it. We separately control for gender, the number of 
children, and an interaction term of these variables, so any effects of being occupied with childcare should be captured by these variables.

Table 5: Self-employment entry probability conditional on determinants of health insurance costs

\begin{tabular}{|c|c|c|c|}
\hline & Full sample & Men & Women \\
\hline Paying SHI member & $\begin{array}{l}-0.4090 * * * \\
(0.0752)\end{array}$ & $\begin{array}{l}-0.5132 * * * \\
(0.0907)\end{array}$ & $\begin{array}{l}-0.0438 \\
(0.1259)\end{array}$ \\
\hline Family insurance & $\begin{array}{l}-0.7497 * * * \\
(0.0940)\end{array}$ & $\begin{array}{l}-0.9016 * * * \\
(0.1759)\end{array}$ & $\begin{array}{l}-0.5446 * * * \\
(0.1364)\end{array}$ \\
\hline Poor health & $\begin{array}{l}-0.0366 \\
(0.0233)\end{array}$ & $\begin{array}{l}-0.0852^{* * * *} \\
(0.0315)\end{array}$ & $\begin{array}{l}0.0148 \\
(0.0343)\end{array}$ \\
\hline Age & $\begin{array}{l}-0.0073 \\
(0.0056)\end{array}$ & $\begin{array}{l}-0.0015 \\
(0.0092)\end{array}$ & $\begin{array}{l}-0.0044 \\
(0.0071)\end{array}$ \\
\hline Supplementary PHI & $\begin{array}{l}0.0257 \\
(0.0534)\end{array}$ & $\begin{array}{l}0.1199 \\
(0.0758)\end{array}$ & $\begin{array}{l}-0.0473 \\
(0.0741)\end{array}$ \\
\hline No. family insured kids & $\begin{array}{l}-0.0592 * \\
(0.0305)\end{array}$ & $\begin{array}{l}-0.0568 \\
(0.0395)\end{array}$ & $\begin{array}{l}-0.0599 \\
(0.0498)\end{array}$ \\
\hline Spouse family insured & $\begin{array}{l}0.1137 \\
(0.3049)\end{array}$ & $\begin{array}{l}0.2154 \\
(0.3907)\end{array}$ & $\begin{array}{l}-2.6913 \\
(2.9554)\end{array}$ \\
\hline Age of spouse & $\begin{array}{l}0.0002 \\
(0.0006)\end{array}$ & $\begin{array}{l}0.0133 * * \\
(0.0067)\end{array}$ & $\begin{array}{l}-0.0001 \\
(0.0020)\end{array}$ \\
\hline Spouse family insured $*$ age of spouse & $\begin{array}{l}-0.0004 \\
(0.0065)\end{array}$ & $\begin{array}{l}-0.0089 \\
(0.0084)\end{array}$ & $\begin{array}{l}0.1677 * * \\
(0.0715)\end{array}$ \\
\hline Spouse paying SHI & $\begin{array}{l}0.0371 \\
(0.0745)\end{array}$ & $\begin{array}{l}-0.0952 \\
(0.1183)\end{array}$ & $\begin{array}{l}0.0784 \\
(0.0972)\end{array}$ \\
\hline Spousal poor health & $\begin{array}{l}-0.0625 * * \\
(0.0307)\end{array}$ & $\begin{array}{l}-0.0791 * \\
(0.0468)\end{array}$ & $\begin{array}{l}-0.0479 \\
(0.0427)\end{array}$ \\
\hline Spouse family insured $*$ spousal poor health & $\begin{array}{l}0.0442 \\
(0.0788)\end{array}$ & $\begin{array}{l}0.0856 \\
(0.0883)\end{array}$ & $\begin{array}{l}-5.2962 * * * \\
(0.9455)\end{array}$ \\
\hline Spousal labor inc. $(€ 100)$ & $\begin{array}{l}0.0004 \\
(0.0008)\end{array}$ & $\begin{array}{l}-0.0013 \\
(0.0023)\end{array}$ & $\begin{array}{l}0.0012 \\
(0.0008)\end{array}$ \\
\hline Female & $\begin{array}{l}-0.3861 * * * \\
(0.0546)\end{array}$ & & \\
\hline No. of children & $\begin{array}{l}0.1306 * * * \\
(0.0347)\end{array}$ & $\begin{array}{l}0.1260 * * * \\
(0.0418)\end{array}$ & $\begin{array}{l}0.0208 \\
(0.0472)\end{array}$ \\
\hline Female $*$ no. of children & $\begin{array}{l}-0.1272 * * * \\
(0.0443)\end{array}$ & & \\
\hline Further control variables & Yes & Yes & Yes \\
\hline$\rho$ & -0.0525 & -0.1919 & -0.1346 \\
\hline Test of $\rho=0: p$-value & $\begin{array}{l}0.6084 \\
-481219268\end{array}$ & $\begin{array}{l}0.0006 \\
-230668726\end{array}$ & $\begin{array}{l}0.2637 \\
-245214381\end{array}$ \\
\hline $\begin{array}{l}\text { Log likelihood } \\
\text { Observations }\end{array}$ & $\begin{array}{l}-48,121.9268 \\
92,515\end{array}$ & $\begin{array}{l}-23,066.8726 \\
44,023\end{array}$ & $\begin{array}{l}-24,521.4381 \\
48,492\end{array}$ \\
\hline Selected observations & 64,773 & 33,012 & 31,761 \\
\hline Mean outcome & 0.0113 & 0.0129 & 0.0099 \\
\hline
\end{tabular}

Notes: Discrete time hazard rate model specified as a probit model with selection correction. The table shows probit coefficients of selected variables in the transition equation; the estimated selection equation and the coefficients of the other control variables, which are the same as in Table 3, are available from the authors on request. Average marginal effects are displayed in Table A 3 in the Appendix. The dependent variable is a binary indicator of entry into self-employment between years $t$ and $t+1$. Standard errors are robust to heteroscedasticity and clustering at the individual level. $\rho$ is the selection correction term. Definitions of the variables appear in Table A 2.

$* / * * / * * *$ : Significance of the coefficient at the $10 \% / 5 \% / 1 \%$ level.

Source: Authors' calculations based on SOEPv29, 2000-2012. 
A higher number of children covered under free family insurance decreases the entry probability for all genders, although this is significant only in the larger pooled sample, presumably due to the high correlation with the number of children in the household. The negative effect of children under family insurance confirms expectations, because these children lose their free family insurance if the employed parent moves to self-employment and chooses PHI, unless the other parent is also employed and covered under SHI. Again, voluntary SHI may be expensive, and PHI is often the more attractive option for the control group who do not have children covered under family insurance. Interestingly, the number of children in the household, independent of family insurance coverage, has a positive partial effect for men. This shows that we are able to separate opposing effects: On the one hand, an effect of the family situation that is unrelated to health insurance costs and may be related to the wish to have flexibility in the timing and location of work, and on the other hand, the pure deterring effect of the additional health insurance costs.

We expect that a spouse covered under free family insurance locks in the partner who is an employee and a paying SHI member, because a switch to self-employment and purchase of PHI would imply that the spouse loses family insurance. We anticipate this barrier to be higher if the spouse covered under family insurance is in poor health or older, because this would make PHI more expensive. Therefore, we include interaction terms. These turn out to be significant for women only; the interaction term with bad health has the expected sign, but not the one with age. The average marginal effects in Table A 4, which take into account the interaction terms, indicate that a spouse covered under family insurance on average decreases the likelihood of entry for women, significant at the $1 \%$ level. For men, there is no significant effect. ${ }^{19}$

\footnotetext{
${ }^{19}$ In the combined sample, there is a smaller positive effect, significant at the $10 \%$ level. This is technically possible due to the nonlinearity of the model, but we do not have an economic explanation for this effect.
} 


\section{Conclusion}

We show that a differential treatment of paid employees and self-employed persons in the health insurance system has significant effects on the entry rate into self-employment, based on representative household panel data for Germany. If the additional costs for health insurance for a self-employed person in comparison to a paid employee increase by 100 euro per month, the probability of entry decreases by about a third of the annual entry rate. This is a large effect, given that the standard deviation of the health insurance cost differential between the options of self-employment and paid employment is 120 euro. Our results further show that a spouse's poor health decreases the entry probability through the higher average health insurance costs when switching to self-employment, but has no significant direct partial effect. Notably, these effects occur in a country with de facto, and since 2009 also de jure, universal health care. The extant literature is limited to the USA with its system of typically employer provided health insurance.

The results imply that policymakers interested in stimulating entrepreneurial activity can use monetary incentives within the health insurance system, not only in the USA. A direct implication of our results is that providing more generous tax deductions of health insurance costs for the self-employed increases the entry rate into self-employment, for example. As a minimum, in future any health care reform, which may be crafted with intentions unrelated to entrepreneurship, should be checked for the incentives and disincentives it creates for selfemployment to avoid unexpected effects on firm formation.

Our approach of estimating a coefficient of the health insurance cost differential has the advantage that the effect size can be compared across countries with different health insurance systems, not limited to countries following the Bismarck model. Future research should exploit the variety of health care systems in the world, including tax-financed public health services as found in the UK, for example, to explore if monetary incentives with regard to health insurance 
have similar effects on self-employment choice in different systems. This avenue will lead to a better understanding of the effects of health care institutions on entrepreneurial activity. In the process of health care reform that many countries are undergoing, not least because of ageing populations, this will allow to take into account the important effects on entrepreneurship, which is becoming increasingly important in innovation based economies.

\section{References}

Acs, Z.J., and D.B. Audretsch, (2005). Entrepreneurship, innovation and technological change. Foundations and Trends in Entrepreneurship 1(4), 1-65.

Benitez-Silva, H., and H. Ni (2008): Health status and health dynamics in an empirical model of expected longevity. Journal of Health Economics 27, 564-584.

Besley, T., J. Hall, and I. Preston (1998): Private and public health insurance in the UK. European Economic Review 42, 491-497.

Besley, T., J. Hall, and I. Preston (1999): The demand for private health insurance: Do waiting lists matter? Journal of Public Economics 72(2), 155-181.

Blanchflower, D.G., A. Oswald, and A. Stutzer (2001). Latent entrepreneurship across nations. European Economic Review 45, 680-691.

Caliendo, M., F.M. Fossen, and A.S. Kritikos (2009). Risk attitudes of nascent entrepreneurs New evidence from an experimentally-validated survey. Small Business Economics 32(2), 153-167.

Caliendo, M., F.M. Fossen, and A.S. Kritikos (2010): The impact of risk attitudes on entrepreneurial survival. Journal of Economic Behavior and Organization 76, 45-63.

Caliendo, M., F.M. Fossen, A.S. Kritikos, and M. Wetter (2014): The gender gap in entrepreneurship: Not just a matter of personality. Forthcoming in: CESifo Economic Studies, doi: 10.1093/cesifo/ifu023. Published online:

http://cesifo.oxfordjournals.org/content/early/2014/07/07/cesifo.ifu023.full.

Cameron, A.C., and P.K. Trivedi (2005): Microeconometrics: Methods and applications. Cambridge, UK: Cambridge University Press.

Carree, M.A., and A.R. Thurik (2003): The impact of entrepreneurship on economic growth. In Z.J. Acs and D.B. Audretsch (Eds.), Handbook of entrepreneurship research, 437-471. Boston, MA: Kluwer Academic Publishers. 
Chetty, R., A. Looney, and K. Kroft (2009): Salience and taxation: Theory and evidence. American Economic Review 99(4), 1145-1177.

Dunn, T., and D. Holtz-Eakin (2000): Financial capital, human capital, and the transition to self-employment: Evidence from intergenerational links. Journal of Labor Economics 18, 282-305.

Fairlie, R.W., K. Kapur, and S. Gates (2011): Is employer-based health insurance a barrier to entrepreneurship? Journal of Health Economics 30(1), 146-162.

Federal Ministry of Health (2013): Daten des Gesundheitswesens 2013. [Data on Health Care 2013.] https://www.bundesgesundheitsministerium.de/fileadmin/dateien/Publikationen/ Gesundheit/Broschueren/Daten_des_Gesundheitswesens_2013.pdf (last accessed: January $27,2015)$.

Georgellis, Y., and H.J. Wall (2005): Gender differences in self-employment. International Review of Applied Economics 19, 321-42.

Gerlinger, T., and R. Schmuckler (2009): A long farewell to the Bismarck system: Incremental change in the German health insurance system. German Policy Studies 5(1), 3-20.

Gilleskie, D.B., and B.F. Lutz (2002): The impact of employer-provided health insurance on dynamic employment transitions. Journal of Human Resources 37(1), 129-162.

Gress, S., A. Walendzik, and J. Wasem (2005): Nichtversicherte Personen im Krankenversicherungssystem der Bundesrepublik Deutschland: Bestandsaufnahme und Lösungsmöglichkeiten. [Non-insured persons in Germany’s health insurance system: Stock taking and possible solutions]. Discussion Paper of the Faculty of Business Administration and Economics 147, University of Duisburg-Essen.

Gruber, J. (2000): Health insurance and the labor market. In A.J. Culyer and J.P. Newhouse (Eds.), Handbook of health economics, Volume 1a, 646-706. New York, NY: NorthHolland.

Gruber, J., and J. Poterba (1994): Tax incentives and the decision to purchase health insurance: Evidence from the self-employed. Quarterly Journal of Economics 109(3), 701-733.

Gumus, G., and T.L. Regan (2013): Tax incentives as a solution to the uninsured: Evidence from the self-employed. Inquiry-The Journal of Health Care Organization, Provision, and Financing 50(4), 275-295.

Gumus, G., and T.L. Regan (2014): Self-employment and the role of health insurance in the U.S.. Forthcoming in: Journal of Business Venturing. Published online: http://dx.doi.org/10.1016/j.jbusvent.2014.01.001.

Gurley-Calvez, T. (2011): Will tax-based health insurance reforms help the self-employed stay in business? Contemporary Economic Policy 29(3), 441-460. 
Haan, P., and M. Myck (2009): Dynamics of health and labor market risks. Journal of Health Economics 28, 1116-1125.

Heckman, James J. (1979): Sample selection bias as a specification error. Econometrica 47(1), 153-161.

Heim, B.T., and I.Z. Lurie (2009): Do increased premium subsidies affect how much health insurance is purchased? Evidence from the self-employed. Journal of Health Economics 28(6), 1197-1210.

Heim, B.T., and I.Z. Lurie (2010): The effect of self-employed health insurance subsidies on self-employment. Journal of Public Economics 94, 995-1007.

Holtz-Eakin, D., J.R. Penrod, and H.S. Rosen (1996): Health insurance and the supply of entrepreneurs. Journal of Public Economics 62(1), 209-235.

Jackson, S. (2010): Mulling over Massachusetts: Health insurance mandates and entrepreneurs. Entrepreneurship Theory and Practice 34(5), 909-931.

Jenkins, S.P. (1995): Easy estimation methods for discrete-time duration models. Oxford Bulletin of Economics and Statistics 57, 129-138

Jones, M.K., and P.L. Latreille (2011): Disability and self-employment: Evidence for the UK. Applied Economics 43(27), 4161-4178.

Kalwij, A., and F. Vermeulen (2008): Health and labour force participation of older people in Europe: What do objective health indicators add to the analysis? Health Economics 17(5), $619-638$.

Lewin-Epstein, N., and E. Yuchtman-Yaar (1991): Health risks of self-employment. Work and Occupations 18(3), 291-312.

Lombard, K.V. (2001): Female self-employment and demand for flexible, nonstandard work schedules. Economic Inquiry 39(2), 214-237.

Madrian, B.C. (1994): Employment-based health insurance and job mobility: Is there evidence of job-lock? Quarterly Journal of Economics 109(1), 27-54.

McFadden, D.L. (1974): Conditional logit analysis of qualitative choice behavior. In P. Zarembka (Ed.), Frontiers in econometrics, 105-142. New York City, NY: Academic Press.

Ooghe, E., E. Schokkaert, and J. Flechet (2003): The incidence of social security contributions: An empirical analysis. Empirica 30, 81-106.

Parker, S.C. (2009): The economics of entrepreneurship. Cambridge, UK: Cambridge University Press.

Parker, S.C., and J.C. Rougier (2007): The retirement behaviour of the self-employed in Britain. Applied Economics 39(6), 697-713. 
Perry, C.W., and H.S. Rosen (2004). The self-employed are less likely than wage earners to have health insurance than wage-earners. So what? In D. Holtz-Eakin and H.S. Rosen (Eds.), Public policy and the economics of entrepreneurship, 23-58. Cambridge, MA: MIT Press.

Schmitz, H., and N.R. Ziebarth (2011). In absolute or relative terms? How framing prices affects the consumer price sensitivity of health plan choice. IZA Discussion Paper 6241, Institute for the Study of Labor.

Selden, T.M. (2009): The impact of increased tax subsidies on the insurance coverage of selfemployed families: Evidence from the 1996-2004 Medical Expenditure Panel Survey. Journal of Human Resources 44(1), 115-139.

Steiner, V., K. Wrohlich, P. Haan, and J. Geyer (2012): Documentation of the tax-benefit microsimulation model STSM, version 2012. DIW Data Documentation 63, German Institute for Economic Research.

Sueyoshi, G. T. (1995): A class of binary response models for grouped duration data. Journal of Applied Econometrics 10, 411-431.

Van de Ven, W.P.M.M., and B.M.S. Van Praag, (1981): The demand for deductibles in private health insurance: A probit model with sample selection. Journal of Econometrics 17, 229252.

Van Praag, C.M., and P.H. Versloot (2007): What is the value of entrepreneurship? A review of recent research. Small Business Economics 29(4), 351-382.

Velamuri, M. (2012): Taxes, health insurance, and women's self-employment. Contemporary Economic Policy 30(2), 162-177.

Verheul, I., S. Wennekers, D. Audretsch, and R. Thurik (2002): An Eclectic Theory of Entrepreneurship: Policies, Institutions and Culture. In D. Audretsch, R. Thurik, I. Verheul, and S. Wennekers (Eds.), Entrepreneurship: Determinants and policy in a European-US comparison. Economics of Science, Technology and Innovation 27, 11-81. New York, NY: Springer Science+Business Media.

Wagner, G.G., J.R. Frick, and J. Schupp (2007): The German Socio-Economic Panel Study (SOEP). Scope, evolution and enhancements. Journal of Applied Social Science Studies 127(1), 139-170.

Wellington, A.J. (2001): Health insurance coverage and entrepreneurship. Contemporary Economic Policy 19(4), 465-478.

Zissimopoulos, J.M., and L.A. Karoly (2007): Transitions to self-employment at older ages: The role of wealth, health, health insurance and other factors. Labour Economics 14, 269295. 


\section{Appendix A: Supplementary tables}

Table A 1: Contribution rates of (groups of) statutory health insurance funds

\begin{tabular}{llllllllll}
\hline \hline Year & AOK* & BKK* & IKK* & BEK & DAK & KKH & TK & KBS & Average \\
\hline 2000 & 13.82 & 12.59 & 13.73 & 13.90 & 13.80 & 13.90 & 13.20 & 13.50 & 13.57 \\
2001 & 13.99 & 12.55 & 13.84 & 13.90 & 13.80 & 13.90 & 13.20 & 13.10 & 13.58 \\
2002 & 14.25 & 13.03 & 14.23 & 14.50 & 14.50 & 14.50 & 13.70 & 12.90 & 13.98 \\
2003 & 14.47 & 13.66 & 14.30 & 14.90 & 15.20 & 14.80 & 13.70 & 12.90 & 14.31 \\
2004 & 14.39 & 13.90 & 14.03 & 14.75 & 14.70 & 14.40 & 13.70 & 12.55 & 14.22 \\
2005 & 13.89 & 13.42 & 13.69 & 14.25 & 14.25 & 13.70 & 13.25 & 11.95 & 13.73 \\
2006 & 13.53 & 13.04 & 12.90 & 13.80 & 13.80 & 13.20 & 13.00 & 11.80 & 13.31 \\
2007 & 14.35 & 13.53 & 13.04 & 14.40 & 14.50 & 13.90 & 13.50 & 12.70 & 13.90 \\
2008 & 14.35 & 13.86 & 13.06 & 14.40 & 14.50 & 13.90 & 13.80 & 12.70 & 14.00 \\
Since 2009 & & & \multicolumn{7}{c}{ Unique contribution rate: 15.5} \\
\hline
\end{tabular}

* Average over the members of the groups.

Abbreviations of names of German statutory health insurance funds: AOK = Allgemeine Ortskrankenkasse; $\mathrm{BKK}=$ Betriebskrankenkasse $; \mathrm{IKK}=$ Innungskrankenkasse $; \mathrm{BEK}=$ Barmer Ersatzkasse $;$ DAK = Deutsche Angestellten-Krankenkasse $; \mathrm{KKH}=$ Kaufmännische Krankenkasse $; \mathrm{TK}=$ Techniker Krankenkasse $;$ KBS = Deutsche Rentenversicherung Knappschaft-Bahn-See. 
Table A 2: Description of variables

\begin{tabular}{|c|c|}
\hline Variable & Description \\
\hline HI cost diff. $(€ 100)$ & $\begin{array}{l}\text { Minimum health insurance cost differential between a household member's } \\
\text { alternatives of self-employment and paid employment for the total household after } \\
\text { taxes. }\end{array}$ \\
\hline Paying SHI member & $\begin{array}{l}\text { Dummy for a person covered under and paying contributions for statutory health } \\
\text { insurance (SHI). }\end{array}$ \\
\hline Family insurance & $\begin{array}{l}\text { Dummy for a person covered under contribution-free family insurance through the } \\
\text { SHI membership of a spouse or parent. }\end{array}$ \\
\hline Private health insurance & Dummy for person currently covered under private health insurance (PHI). \\
\hline Supplementary PHI & $\begin{array}{l}\text { Dummy for holding supplementary private insurance. Imputed from observations of } \\
\text { the same person in other years, when missing. }\end{array}$ \\
\hline No. family insured kids & $\begin{array}{l}\text { Number of children in the household covered under contribution-free family } \\
\text { insurance through the SHI membership of a spouse or parent. }\end{array}$ \\
\hline Poor health & Self-assessed current health on a scale from 1 (very good) to 5 (very good). \\
\hline Disability degree & Officially assessed and certified degree of disability. \\
\hline Age & Age of person. \\
\hline Female & Dummy for women. \\
\hline No. of children & Number of children under 17 years of age in the household. \\
\hline Spouse family insured & $\begin{array}{l}\text { Dummy for a person whose spouse is covered under his or her statutory health } \\
\text { insurance membership. }\end{array}$ \\
\hline Age of spouse & Age of a person's spouse. \\
\hline Spouse paying SHI & $\begin{array}{l}\text { Dummy for a person whose spouse is covered under and paying contributions for } \\
\text { statutory health insurance. }\end{array}$ \\
\hline Spousal poor health & $\begin{array}{l}\text { Self-assessed current health on a scale from } 1 \text { (very good) to } 5 \text { (very good) of a } \\
\text { person's spouse. }\end{array}$ \\
\hline Spousal disability deg. & Officially assessed and certified degree of disability of a person's spouse. \\
\hline Labor income $(€ 100)$ & Labor income per month before tax, deflated by the CPI (in $€ 100)$. \\
\hline Spousal labor inc. $(€ 100)$ & $\begin{array}{l}\text { Labor income per month before tax, deflated by the CPI (in } € 100 \text { ) of a person's } \\
\text { spouse. }\end{array}$ \\
\hline High school degree & $\begin{array}{l}\text { Dummy for a person who has completed secondary education with a university } \\
\text { entrance qualification. }\end{array}$ \\
\hline Apprenticeship & Dummy for a person who has completed vocational training. \\
\hline Higher techn. college & $\begin{array}{l}\text { Dummy for a person who has completed a higher technical college, a health care } \\
\text { school, or civil service training. }\end{array}$ \\
\hline University degree & Dummy for a person who has a university degree. \\
\hline Married & Dummy for a married person. \\
\hline East & Dummy for a person living in the area of former East Germany or Berlin. \\
\hline South & Dummy for a person living in Baden-Wuerttemberg or Bavaria. \\
\hline North & Dummy for a person living in Schleswig-Holstein or Lower Saxony. \\
\hline Work exp. $(10 \mathrm{yrs})^{\mathrm{a}}$ & Prior work experience (in years divided by 10 ). \\
\hline Unemployment exp. ${ }^{\text {a }}$ & Unemployment experience (in years). \\
\hline German citizenship & Dummy for a person holding German citizenship. \\
\hline Self-employed father & $\begin{array}{l}\text { Dummy for a person whose father was self-employed when the respondent was } 15 \\
\text { years old. }\end{array}$ \\
\hline Willingness to take risks & General willingness to take risks (scale $0-10$, imputed if missing). \\
\hline Duration employment spell ${ }^{\mathrm{a}}$ & $\begin{array}{l}\text { Number of years spent in the current spell of paid employment (used to generate set } \\
\text { of } 11 \text { dummy variables). }\end{array}$ \\
\hline
\end{tabular}

Note: Dummy variables equal 1 if condition holds and 0 otherwise.

${ }^{a}$ Uses information from the lifetime employment history in the SOEP. 
Table A 3: Average marginal effects of further variables

\begin{tabular}{|c|c|c|c|c|c|c|c|c|}
\hline & \multicolumn{5}{|c|}{ Estimations from Table 3} & \multicolumn{3}{|c|}{ Estimations from Table 5} \\
\hline & Full sample & Men & Women & Inc. splines & Altern. health & Full Sample & Men & Women \\
\hline HI cost diff. $(€ 100)$ & $\begin{array}{l}-0.0038 * * * \\
(0.0010)\end{array}$ & $\begin{array}{l}-0.0068 * * * \\
(0.0016)\end{array}$ & $\begin{array}{l}-0.0007 \\
(0.0012)\end{array}$ & $\begin{array}{l}-0.0037 * * * \\
(0.0009)\end{array}$ & $\begin{array}{l}-0.0039 * * * \\
(0.0010)\end{array}$ & & & \\
\hline Poor health & $\begin{array}{l}-0.0025^{*} \\
(0.0013)\end{array}$ & $\begin{array}{l}-0.0057 * * \\
(0.0023)\end{array}$ & $\begin{array}{l}-0.0004 \\
(0.0015)\end{array}$ & $\begin{array}{l}-0.0022 * \\
(0.0012)\end{array}$ & & $\begin{array}{l}-0.0019 \\
(0.0012)\end{array}$ & $\begin{array}{l}-0.0059 * * * \\
(0.0020)\end{array}$ & $\begin{array}{l}0.0005 \\
(0.0014)\end{array}$ \\
\hline Disability degree & & & & & $\begin{array}{l}-0.0199 * * \\
(0.0099)\end{array}$ & & & \\
\hline Age & $\begin{array}{l}-0.0007 * * * \\
(0.0003)\end{array}$ & $\begin{array}{l}-0.0006 \\
(0.0007)\end{array}$ & $\begin{array}{l}-0.0007 * * \\
(0.0003)\end{array}$ & $\begin{array}{l}-0.0006 * * \\
(0.0003)\end{array}$ & $\begin{array}{l}-0.0008 * * * \\
(0.0003)\end{array}$ & $\begin{array}{l}-0.0005^{* *} \\
(0.0002)\end{array}$ & $\begin{array}{l}-0.0004 \\
(0.0006)\end{array}$ & $\begin{array}{l}-0.0004^{*} \\
(0.0002)\end{array}$ \\
\hline Supplementary PHI & $\begin{array}{l}-0.0003 \\
(0.0028)\end{array}$ & $\begin{array}{l}0.0022 \\
(0.0052)\end{array}$ & $\begin{array}{l}-0.0004 \\
(0.0031)\end{array}$ & $\begin{array}{l}-0.0004 \\
(0.0026)\end{array}$ & $\begin{array}{l}-0.0003 \\
(0.0028)\end{array}$ & $\begin{array}{l}0.0013 \\
(0.0027)\end{array}$ & $\begin{array}{l}0.0078 \\
(0.0049)\end{array}$ & $\begin{array}{l}-0.0019 \\
(0.0029)\end{array}$ \\
\hline Age of spouse & $\begin{array}{l}0.0000 \\
(0.0000)\end{array}$ & $\begin{array}{l}0.0008 * \\
(0.0004)\end{array}$ & $\begin{array}{l}0.0000 \\
(0.0000)\end{array}$ & $\begin{array}{l}0.0000 \\
(0.0000)\end{array}$ & $\begin{array}{l}0.0000 \\
(0.0000)\end{array}$ & $\begin{array}{l}0.0000 \\
(0.0000)\end{array}$ & $\begin{array}{l}0.0007^{*} \\
(0.0004)\end{array}$ & $\begin{array}{l}-0.0000 \\
(0.0001)\end{array}$ \\
\hline Spousal poor health & $\begin{array}{l}-0.0022 \\
(0.0015)\end{array}$ & $\begin{array}{l}-0.0026 \\
(0.0026)\end{array}$ & $\begin{array}{l}-0.0018 \\
(0.0018)\end{array}$ & $\begin{array}{l}-0.0021 \\
(0.0014)\end{array}$ & & $\begin{array}{l}-0.0029 * * \\
(0.0014)\end{array}$ & $\begin{array}{l}-0.0044 \\
(0.0027)\end{array}$ & $\begin{array}{l}-0.0019 \\
(0.0017)\end{array}$ \\
\hline Spousal disability deg. & & & & & $\begin{array}{l}0.0024 \\
(0.0120)\end{array}$ & & & \\
\hline No. of children & $\begin{array}{l}0.0025 * * \\
(0.0012)\end{array}$ & $\begin{array}{l}0.0070 * * * \\
(0.0021)\end{array}$ & $\begin{array}{l}-0.0017 \\
(0.0017)\end{array}$ & $\begin{array}{l}0.0025 * * \\
(0.0011)\end{array}$ & $\begin{array}{l}0.0027 * * \\
(0.0012)\end{array}$ & $\begin{array}{l}0.0039 * * * \\
(0.0015)\end{array}$ & $\begin{array}{l}0.0076 * * * \\
(0.0027)\end{array}$ & $\begin{array}{l}0.0006 \\
(0.0018)\end{array}$ \\
\hline Female & $\begin{array}{l}-0.0342 * * * \\
(0.0042)\end{array}$ & & & $\begin{array}{l}-0.0326 * * * \\
(0.0040)\end{array}$ & $\begin{array}{l}-0.0352 * * * \\
(0.0043)\end{array}$ & $\begin{array}{l}-0.0265 * * * \\
(0.0032)\end{array}$ & & \\
\hline Paying SHI member & & & & & & $\begin{array}{l}-0.0205 * * * \\
(0.0039)\end{array}$ & $\begin{array}{l}-0.0333 * * * \\
(0.0060)\end{array}$ & $\begin{array}{l}-0.0017 \\
(0.0050)\end{array}$ \\
\hline Family insurance & & & & & & $\begin{array}{l}-0.0376 * * * \\
(0.0051)\end{array}$ & $\begin{array}{l}-0.0585 * * * \\
(0.0116)\end{array}$ & $\begin{array}{l}-0.0217 * * * \\
(0.0059)\end{array}$ \\
\hline No. family insured kids & & & & & & $\begin{array}{l}-0.0030^{*} \\
(0.0015)\end{array}$ & $\begin{array}{l}-0.0037 \\
(0.0026)\end{array}$ & $\begin{array}{l}-0.0024 \\
(0.0020)\end{array}$ \\
\hline Spouse family insured & & & & & & $\begin{array}{l}0.0113^{*} \\
(0.0066)\end{array}$ & $\begin{array}{l}0.0027 \\
(0.0098)\end{array}$ & $\begin{array}{l}-0.0188 * * * \\
(0.0027)\end{array}$ \\
\hline Spouse paying SHI & & & & & & $\begin{array}{l}0.0019 \\
(0.0037)\end{array}$ & $\begin{array}{l}-0.0062 \\
(0.0077)\end{array}$ & $\begin{array}{l}0.0031 \\
(0.0039)\end{array}$ \\
\hline Observations & & & & & & 88,721 & 42,375 & 46,346 \\
\hline
\end{tabular}

Notes: The table shows average marginal effects for selected continuous variables and average discrete changes from the base level for selected binary variables. The estimates are conditional on being selected into the main estimation sample, i.e. on being a paid employee. They are based on the estimated models of Table 3 and Table 5. Standard errors are robust to heteroscedasticity and clustering at the individual level. */**/***: Significance of the coefficient at the $10 \% / 5 \% / 1 \%$ level.

Source: Authors' calculations based on SOEPv29, 2000-2012. 
Table A 4: Selection into being a regular employee

\begin{tabular}{|c|c|c|c|c|c|}
\hline & Full Sample & Men & Women & $\begin{array}{l}\text { Income } \\
\text { splines }\end{array}$ & $\begin{array}{l}\text { Alt. health } \\
\text { measure }\end{array}$ \\
\hline Poor health & $\begin{array}{l}-0.0378 * * * \\
(0.0103)\end{array}$ & $\begin{array}{l}-0.0558 * * * \\
(0.0153)\end{array}$ & $\begin{array}{l}-0.0185 \\
(0.0140)\end{array}$ & $\begin{array}{l}-0.0378 * * * \\
(0.0103)\end{array}$ & \\
\hline Disability degree & & & & & $\begin{array}{l}-0.0562 \\
(0.0801)\end{array}$ \\
\hline Age & $\begin{array}{l}-0.0713 * * * \\
(0.0025)\end{array}$ & $\begin{array}{l}-0.0367 * * * \\
(0.0061)\end{array}$ & $\begin{array}{l}-0.0752 * * * \\
(0.0026)\end{array}$ & $\begin{array}{l}-0.0713 * * * \\
(0.0025)\end{array}$ & $\begin{array}{l}-0.0718 * * * \\
(0.0025)\end{array}$ \\
\hline Age of spouse & $\begin{array}{l}-0.0026 \\
(0.0019)\end{array}$ & $\begin{array}{l}-0.0143 * * * \\
(0.0034)\end{array}$ & $\begin{array}{l}-0.0010 \\
(0.0009)\end{array}$ & $\begin{array}{l}-0.0026 \\
(0.0019)\end{array}$ & $\begin{array}{l}-0.0025 \\
(0.0019)\end{array}$ \\
\hline Spousal poor health & $\begin{array}{l}0.0269 * * \\
(0.0134)\end{array}$ & $\begin{array}{l}0.0103 \\
(0.0205)\end{array}$ & $\begin{array}{l}0.0520 * * * \\
(0.0175)\end{array}$ & $\begin{array}{l}0.0269 * * \\
(0.0134)\end{array}$ & \\
\hline spouse_disabl_share & & & & & $\begin{array}{l}0.0627 \\
(0.0826)\end{array}$ \\
\hline Spousal labor inc. $(€ 100)$ & $\begin{array}{l}-0.0031 * * * \\
(0.0005)\end{array}$ & $\begin{array}{l}-0.0023 * * \\
(0.0011)\end{array}$ & $\begin{array}{l}-0.0022 * * * \\
(0.0005)\end{array}$ & $\begin{array}{l}-0.0031 * * * \\
(0.0005)\end{array}$ & $\begin{array}{l}-0.0031 * * * \\
(0.0005)\end{array}$ \\
\hline Female & $\begin{array}{l}0.2334 * * * \\
(0.0291)\end{array}$ & & & $\begin{array}{l}0.2334 * * * \\
(0.0291)\end{array}$ & $\begin{array}{l}0.2334 * * * \\
(0.0291)\end{array}$ \\
\hline No. of children & $\begin{array}{l}-0.0906 * * * \\
(0.0199)\end{array}$ & $\begin{array}{l}-0.1051 * * * \\
(0.0208)\end{array}$ & $\begin{array}{l}-0.0575^{* * * *} \\
(0.0172)\end{array}$ & $\begin{array}{l}-0.0906^{* * * *} \\
(0.0199)\end{array}$ & $\begin{array}{l}-0.0909 * * * \\
(0.0200)\end{array}$ \\
\hline Female $*$ no. of children & $\begin{array}{l}0.0191 \\
(0.0254)\end{array}$ & & & $\begin{array}{l}0.0191 \\
(0.0254)\end{array}$ & $\begin{array}{l}0.0197 \\
(0.0254)\end{array}$ \\
\hline High school degree & $\begin{array}{l}0.0960 * * * \\
(0.0327)\end{array}$ & $\begin{array}{l}-0.0042 \\
(0.0521)\end{array}$ & $\begin{array}{l}0.1046 * * \\
(0.0429)\end{array}$ & $\begin{array}{l}0.0960 * * * \\
(0.0327)\end{array}$ & $\begin{array}{l}0.0982 * * * \\
(0.0327)\end{array}$ \\
\hline Apprenticeship & $\begin{array}{l}0.2019 * * * \\
(0.0305)\end{array}$ & $\begin{array}{l}0.1831 * * * \\
(0.0458)\end{array}$ & $\begin{array}{l}0.2014 * * * \\
(0.0409)\end{array}$ & $\begin{array}{l}0.2019 * * * \\
(0.0305)\end{array}$ & $\begin{array}{l}0.2025 * * * \\
(0.0305)\end{array}$ \\
\hline Higher techn. college & $\begin{array}{l}0.1464 * * * \\
(0.0346)\end{array}$ & $\begin{array}{l}0.0865 \\
(0.0541)\end{array}$ & $\begin{array}{l}0.1757 * * * \\
(0.0450)\end{array}$ & $\begin{array}{l}0.1464 * * * \\
(0.0346)\end{array}$ & $\begin{array}{l}0.1462 * * * \\
(0.0346)\end{array}$ \\
\hline University degree & $\begin{array}{l}0.1694 * * * \\
(0.0373)\end{array}$ & $\begin{array}{l}0.0834 \\
(0.0580)\end{array}$ & $\begin{array}{l}0.1382 * * * \\
(0.0502)\end{array}$ & $\begin{array}{l}0.1694 * * * \\
(0.0373)\end{array}$ & $\begin{array}{l}0.1718 * * * \\
(0.0373)\end{array}$ \\
\hline Married & $\begin{array}{l}0.1900 * * * \\
(0.0284)\end{array}$ & $\begin{array}{l}0.2785 * * * \\
(0.0456)\end{array}$ & $\begin{array}{l}0.0689 * \\
(0.0368)\end{array}$ & $\begin{array}{l}0.1900 * * * \\
(0.0284)\end{array}$ & $\begin{array}{l}0.1895 * * * \\
(0.0284)\end{array}$ \\
\hline East & $\begin{array}{l}-0.0096 \\
(0.0299)\end{array}$ & $\begin{array}{l}-0.0820 * \\
(0.0430)\end{array}$ & $\begin{array}{l}0.0805^{*} \\
(0.0416)\end{array}$ & $\begin{array}{l}-0.0096 \\
(0.0299)\end{array}$ & $\begin{array}{l}-0.0086 \\
(0.0300)\end{array}$ \\
\hline South & $\begin{array}{l}0.0511 * \\
(0.0291)\end{array}$ & $\begin{array}{l}0.1101 * * \\
(0.0447)\end{array}$ & $\begin{array}{l}0.0128 \\
(0.0386)\end{array}$ & $\begin{array}{l}0.0511 * \\
(0.0291)\end{array}$ & $\begin{array}{l}0.0525^{*} \\
(0.0291)\end{array}$ \\
\hline North & $\begin{array}{l}0.0898 * * \\
(0.0387)\end{array}$ & $\begin{array}{l}-0.0085 \\
(0.0606)\end{array}$ & $\begin{array}{l}0.1704 * * * \\
(0.0488)\end{array}$ & $\begin{array}{l}0.0898 * * \\
(0.0387)\end{array}$ & $\begin{array}{l}0.0920 * * \\
(0.0387)\end{array}$ \\
\hline Work exp. (10 yrs) & $\begin{array}{l}1.4091 * * * \\
(0.0424)\end{array}$ & $\begin{array}{l}0.8066 * * * \\
(0.0833)\end{array}$ & $\begin{array}{l}1.6209 * * * \\
(0.0537)\end{array}$ & $\begin{array}{l}1.4091 * * * \\
(0.0424)\end{array}$ & $\begin{array}{l}1.4104 * * * \\
(0.0424)\end{array}$ \\
\hline Work exp. squared & $\begin{array}{l}-0.1821 * * * \\
(0.0094)\end{array}$ & $\begin{array}{l}-0.1087 * * * \\
(0.0143)\end{array}$ & $\begin{array}{l}-0.2303 * * * \\
(0.0128)\end{array}$ & $\begin{array}{l}-0.1821 * * * \\
(0.0094)\end{array}$ & $\begin{array}{l}-0.1823 * * * \\
(0.0094)\end{array}$ \\
\hline Unemployment exp. & $\begin{array}{l}-0.2100 * * * \\
(0.0115)\end{array}$ & $\begin{array}{l}-0.2669 * * * \\
(0.0176)\end{array}$ & $\begin{array}{l}-0.1960 * * * \\
(0.0153)\end{array}$ & $\begin{array}{l}-0.2100^{* * * *} \\
(0.0115)\end{array}$ & $\begin{array}{l}-0.2118^{* * *} \\
(0.0116)\end{array}$ \\
\hline Unempl. exp. squared & $\begin{array}{l}0.0089 * * * \\
(0.0010)\end{array}$ & $\begin{array}{l}0.0103 * * * \\
(0.0015)\end{array}$ & $\begin{array}{l}0.0082 * * * \\
(0.0013)\end{array}$ & $\begin{array}{l}0.0089 * * * \\
(0.0010)\end{array}$ & $\begin{array}{l}0.0090 * * * \\
(0.0010)\end{array}$ \\
\hline German citizenship & $\begin{array}{l}0.1451 * * * \\
(0.0455)\end{array}$ & $\begin{array}{l}0.1242 * \\
(0.0680)\end{array}$ & $\begin{array}{l}0.1419 * * \\
(0.0620)\end{array}$ & $\begin{array}{l}0.1451 * * * \\
(0.0455)\end{array}$ & $\begin{array}{l}0.1441 * * * \\
(0.0455)\end{array}$ \\
\hline Self-employed father & $\begin{array}{l}-0.2902 * * * \\
(0.0435)\end{array}$ & $\begin{array}{l}-0.4629 * * * \\
(0.0631)\end{array}$ & $\begin{array}{l}-0.1259 * * \\
(0.0588)\end{array}$ & $\begin{array}{l}-0.2902 * * * \\
(0.0435)\end{array}$ & $\begin{array}{l}-0.2926 * * * \\
(0.0436)\end{array}$ \\
\hline Willingness to take risks & $\begin{array}{l}-0.0389 * * * \\
(0.0045)\end{array}$ & $\begin{array}{l}-0.0637 * * * \\
(0.0067)\end{array}$ & $\begin{array}{l}-0.0205^{* * * *} \\
(0.0060)\end{array}$ & $\begin{array}{l}-0.0389 * * * \\
(0.0045)\end{array}$ & $\begin{array}{l}-0.0382 * * * \\
(0.0045)\end{array}$ \\
\hline Full set of year dummies & Yes & Yes & Yes & Yes & Yes \\
\hline Children below 3 years & $\begin{array}{l}-0.0032 \\
(0.0339)\end{array}$ & $\begin{array}{l}-0.0302 \\
(0.0349)\end{array}$ & $\begin{array}{l}-0.9129 * * * \\
(0.0340)\end{array}$ & $\begin{array}{l}-0.0031 \\
(0.0339)\end{array}$ & $\begin{array}{l}0.0002 \\
(0.0338)\end{array}$ \\
\hline Children below 6 years & $\begin{array}{l}0.1026 * * * \\
(0.0318)\end{array}$ & $\begin{array}{l}0.0730 * * \\
(0.0323)\end{array}$ & $\begin{array}{l}-0.2427 * * * \\
(0.0279)\end{array}$ & $\begin{array}{l}0.1026 * * * \\
(0.0318)\end{array}$ & $\begin{array}{l}0.0998 * * * \\
(0.0318)\end{array}$ \\
\hline Female $*$ children below 3 & $\begin{array}{l}-0.9142 * * * \\
(0.0475)\end{array}$ & & & $\begin{array}{l}-0.9142 * * * \\
(0.0475)\end{array}$ & $\begin{array}{l}-0.9171 * * * \\
(0.0475)\end{array}$ \\
\hline
\end{tabular}


Table A 4 continued

\begin{tabular}{llllll}
\hline & Full Sample & Men & Women & $\begin{array}{l}\text { Income } \\
\text { splines }\end{array}$ & $\begin{array}{l}\text { Alt. } \\
\text { measure }\end{array}$ \\
\hline Female * children below 6 & $-0.3587^{* * *}$ & & & $-0.3586^{* * *}$ & $-0.3573 * * *$ \\
& $(0.0418)$ & & & $(0.0418)$ & $\begin{array}{l}(0.0419) \\
\text { Constant }\end{array}$ \\
& $1.8271 * * *$ & $2.0987 * * *$ & $1.7326 * * *$ & $1.8272 * * *$ & $1.8139 * * *$ \\
$\rho$ & $(0.0938)$ & $(0.1849)$ & $(0.1083)$ & $(0.0938)$ & $(0.0899)$ \\
Test of $\rho=0: p$-value & -0.0758 & -0.1853 & -0.1010 & -0.0656 & -0.0735 \\
Observations & 0.4714 & 0.0108 & 0.4556 & 0.5456 & 0.4873 \\
Selected observations & 84,300 & 39,462 & 44,838 & 84,300 & 84,265 \\
\hline
\end{tabular}

Notes: The table shows the estimated equations of selection into being a paid employee, which belong to the main estimation results displayed in Table 3. Standard errors are robust to heteroscedasticity and clustering at the individual level. $\rho$ is the selection correction term.

$* / * * / * * *$ : Significance of the coefficient at the $10 \% / 5 \% / 1 \%$ level.

Source: Authors' calculations based on SOEPv29, 2000-2012.

\section{Appendix B: Estimation of private health insurance premiums}

To calculate the HICD, PHI premiums in case of counter-factual self-employment must be predicted. Therefore, we first run an OLS regression of observed private health insurance premiums of actually self-employed persons on characteristics determining PHI premiums. As mentioned before, premiums depend on age, gender, and a health assessment taking place when the PHI contract is signed. This puts the consumer into a risk class. Therefore, we recover the age and health in the year that the self-employed person first entered PHI from the panel data and use them as explanatory variables in the PHI premium regression, along with gender. For all members within a risk class, premiums continue to rise with ageing, but new medical conditions do not affect the premiums anymore, because they are fully insured. We model this by additionally including the duration of the PHI contract.

If more than one family member is covered under PHI, one family member usually pays (and therefore knows about) the total amount paid for all of them. Therefore, the SOEP questionnaire asks if a person with PHI pays premiums and if so, how much and how many persons this covers. We incorporate this in the regression by controlling for a spouse who is included in this PHI amount, and for the number of children included; PHI premiums are lower for children than for adults. We also include information on co-payments, which reduce 
premiums, and eligibility for financial support from the government in case of sickness, which is granted to civil servants and their children and also to the spouse if his or her income remains below a threshold. Information on co-payments is only available in 2000-2001 and 2007-2011, so we only use these years in the regression and control for time dummies.

The estimated coefficients in Table B 1 confirm expectations. Premiums increase with age and poorer health when signing the contract, but also with the duration of the contract, and women pay more. The premium for PHI coverage of a spouse is more than double the amount for an additional child covered. Co-payments in the form of fixed amounts or percentage shares reduce premiums, although the latter effect is insignificant. Government financial support for civil servants and their families decreases average premiums by more than half because PHI only has to cover half the costs in case of sickness, and the civil servants are a comparably low risk group. When using the equation to predict PHI premiums for currently paid employees in the counter-factual case of self-employment, we adjust the variables for a spouse and children that must be covered under PHI according to the household's situation. We also set the copayment amounts and shares to zero. This makes the costs most comparable to SHI, which does not have co-payments (except for small fees of $€ 10$ once a quarter for visiting a doctor since 2004). 
Table B 1: Regression of private health insurance premiums per month

\begin{tabular}{|c|c|}
\hline & Dep. var.: Monthly PHI premiums \\
\hline Age at begin of PHI contract & $\begin{array}{l}16.7597 * * * \\
(3.4231)\end{array}$ \\
\hline Age at begin of PHI contract squared & $\begin{array}{l}-0.1478 * * * \\
(0.0446)\end{array}$ \\
\hline Duration of PHI contract & $\begin{array}{l}9.3461 * * * \\
(1.6214)\end{array}$ \\
\hline Female & $\begin{array}{l}47.3174 * * * \\
(8.6794)\end{array}$ \\
\hline Poor health at begin of PHI contract & $\begin{array}{l}14.7716 * * \\
(6.6515)\end{array}$ \\
\hline Spouse co-insured in PHI & $\begin{array}{l}191.7486 * * * \\
(49.0995)\end{array}$ \\
\hline Additional number of co-insured persons & $\begin{array}{l}67.4930 * * * \\
(10.9221)\end{array}$ \\
\hline Co-payment amount & $\begin{array}{l}-0.0149 * * * \\
(0.0056)\end{array}$ \\
\hline Co-payment share & $\begin{array}{l}-0.3411 \\
(0.4974)\end{array}$ \\
\hline Eligible for civil servant health benefits & $\begin{array}{l}-174.9300 * * * \\
(22.2966)\end{array}$ \\
\hline Year 2001 & $\begin{array}{l}-77.5841 * * * \\
(17.2838)\end{array}$ \\
\hline Year 2007 & $\begin{array}{l}-40.2442 * * * \\
(12.1492)\end{array}$ \\
\hline Year 2008 & $\begin{array}{l}-18.0083 \\
(12.6121)\end{array}$ \\
\hline Year 2009 & $\begin{array}{l}-3.7468 \\
(12.0770)\end{array}$ \\
\hline Year 2010 & $\begin{array}{l}-20.0598 \\
(12.8864)\end{array}$ \\
\hline Constant & $\begin{array}{l}-156.4222 * * \\
(64.5361)\end{array}$ \\
\hline$R^{2}$ & 0.3997 \\
\hline Observations & 689 \\
\hline Mean of the dependent variable & 320.1729 \\
\hline \multicolumn{2}{|c|}{$\begin{array}{l}\text { Notes: The dependent variable in this OLS regression is private health insurance premium pe } \\
\text { month. Heteroscedasticity robust standard errors are in parentheses. Definitions of the variable } \\
\text { appear in Table A } 2 \text {. } \\
* / * * / * * * \text { : Significance of the coefficient at the } 10 \% / 5 \% / 1 \% \text { level. }\end{array}$} \\
\hline
\end{tabular}

